\title{
LANGUAGE AND EDUCATION RIGHTS IN QUEBEC AND CANADA (A LEGISLATIVE HISTORY AND PERSONAL POLITICAL DIARY) $\dagger$
}

\author{
William TetLey, Q.C.*
}

\section{INTRODUCTION}

It was Maurice Duplessis, Premier of Quebec from 1936 to 1939 and again from 1944 to 1959, who presumably said that governments should never legislate on language or education. Carefully following his own precept, he left Catholic education to Quebec's Roman Catholic bishops and Protestant education to Protestant school boards comprised of Protestant middleclass businessmen. Indeed, language was not the subject of any legislation in Duplessis's time.

The death of Duplessis, however, brought change. In 1964, the Lesage Liberal government took the necessary and courageous step of creating a Ministry of Education, ${ }^{1}$ and in 1968, the Bertrand Union Nationale government presented Bill $85,{ }^{2}$ which provided for what is commonly called "freedom of choice"- that is the right of parents to choose the language of education for their children. In 1974, the Bourassa Liberal government adopted Bill 22, ${ }^{3}$ which dealt with both language and education. In 1977, the Parti Québécois government adopted Bill 101, ${ }^{4}$ and finally, the Trudeau government in December 1981 adopted a Resolution to Amend the Constitution of Canada. ${ }^{5}$ Within that Constitutional Amendment is the Canadian Charter of Rights and Freedoms which specifically concerns language and education rights, among other matters. This article is intended to present a politician's view of the foregoing changes in the law and to reveal how the public reacted to such changes.

\footnotetext{
Copyright $(\mathcal{C} 1983$ by Law and Contemporary Problems

$\dagger$ The author is especially appreciative of the assistance of Allan A. Garber, B.A., M.A., LL.B.III of McGill Law Faculty.

* Professor, Faculty of Law, McGill University.

1. An Act to Establish the Department of Education and the Superior Council of Education, ch. 15, 1964 Que. Stat. 89.

2. Loi modifiant la Loi du Ministere de l'Education, la Loi du Conseil Supérieur de l'Education et la Loi de l'Instruction Publique. The bill, however, never became law. It was withdrawn under fire from within and without the government.

3. The Official Language Act, ch. 6, 1974 Que. Stat. 53.

4. La Charte de la langue française, ch. 5, 1977 Que. Stat. 55 (current version at Que. REV. STAT. ch. c-11 (1977)).

5. Adopted in the House of Commons on December 2, 1981, and by the Senate on December 8, 1981. After adoption in the U.K. House of Commons and House of Lords, the Canada Act 1982, received Royal Assent on March 29, 1982. On April 17, 1982, Her Majesty the Queen signed the proclamation in Ottawa which brought into force the Constitution Act, 1982, which is Schedule B of the Canada Act 1982, 1982, ch. 11 (U.K.).
} 
II The Constitution in Respect to Education and to LanguageCANADA

\section{A. The BNA Act, 1867 (The Constitution Act, 1867)}

1. Section 93. Under section 93 of the British North America Act, 1867 (BNA Act), ${ }^{6}$ the provincial legislatures have exclusive jurisdiction to make laws in relation to education, subject to the restriction that such laws shall not prejudicially affect the rights or privileges of the Protestant and Roman Catholic denominational schools. Section 93 is silent as to whether the language of education is protected. The resolution of this issue turns on whether, at the time of Confederation, the denominational schools enjoyed the legal right to determine the language of instruction. It has been decided in the provinces of Ontario and Quebec that no such right existed. ${ }^{7}$ Since the language of education is not protected, it appears that the provincial legislatures must, as ancillary to their exclusive jurisdiction over education, have the power to prescribe the language of instruction in the schools. ${ }^{8}$

2. Section 133. The only express protection of language rights in the BNA Act, 1867, is found in section 133.9 The use of either French or English is permitted in "any pleading or process" in the courts of Canada and Quebec, in debates of the Parliament of Canada, and the Quebec Legislature. ${ }^{10}$ The use of both English and French is required in the published statutes, records, and journals of the federal Parliament and Quebec Legislature." ${ }^{11}$ These statutory guarantees are entrenched and are not subject to "modification by unilateral action of Parliament or of the Quebec Legislature" in as much as they are "part of the Constitution of Canada and Quebec in an indivisible sense." 12

3.Section 92(13). It should also be noted that section 92(13) of the BNA Act, 1867, provides that the legislatures of each province have exclusive legislative authority in respect to property and civil rights. ${ }^{13}$

\section{B. Canadian Bill of Rights}

The Canadian Bill of Rights ${ }^{14}$ was enacted by Parliament in 1960 and has been described by Chief Justice Laskin as a "quasi-constitutional instrument."15 It is not entrenched, and can be amended, overridden, or repealed by an ordinary act of Parliament. Moreover, it applies only to federal statutes and to "matters

6. Can. Rev. Stat. app. II No. 5 (1970)(since April 17, 1982, called the Constitution Act, 1867)[hereinafter cited as BNA Act, 1867].

7. Trustees of the Roman Catholic Separate Schools of Ottawa v. MacKell, [1917] A.C. 62 (P.C.); Protestant School Bd. v. Minister of Educ., 83 D.L.R.3d 645 (1978) (Quebec Super. Ct.).

8. See Hogg, Constitutional Power Over Language, in THE Constrrution AND THE FUTURE OF CANADA 229, 230-32 (Law Society of Upper Canada Special Lectures 1978). This right is now subject to section 23 of the Canadian Charter of Rights and Freedoms.

9. Can. Rev. Stat. app. II No. 5 (1970).

10. Id.

11. Id.

12. Attorney General of Quebec v. Blaikie, 101 D.L.R.3d 394, 400-01 (1980).

13. Can. Rev. Stat. app. II No. 5 (1970).

14. Can. Rev. Stat. app. III (1970).

15. Hogan v. The Queen, [1975] 2 S.C.R. 574, 597. 
coming within the legislative authority of the Parliament of Canada."16 The Canadian Bill of Rights does not protect language rights, except that section 2(g) guarantees a person "the right to the assistance of an interpreter in any proceedings in which he is involved . . . if he does not understand or speak the language in which such proceedings are conducted." 17 The right to an interpreter is available only in proceedings before federal courts, commissions, boards, or tribunals.

\section{Official Languages Act}

Even though the issue of language rights has been a persistent source of controversy in Canadian history, only recently has the concept of an "official language" received legal recognition. Nowhere is the term "official language" used in the BNA Act, 1867, nor is language one of the classes of subjects enumerated in the distribution of legislative powers in sections 91 and 92. In 1969, the Parliament of Canada enacted the Official Languages Act, ${ }^{18}$ which guarantees the equal status of English and French "in all the institutions of the Parliament and Government of Canada." 19 Under section 2 of the Act, the English and French languages are declared the official languages of Canada for all purposes of the Parliament and Government of Canada, with each enjoying equality of status. ${ }^{20}$ The remainder of the Act gives effect to the declaration in section 2 by indicating how and when the official languages are to be used by the departments and agencies of the federal government, judicial, quasi-judicial, administrative bodies, and Crown corporations established by Acts of Parliament.

The competence of Parliament to enact the Official Languages Act was upheld by a unanimous judgment of the Supreme Court of Canada in Jones v. Attorney General of New Brunswick. ${ }^{21}$ The Court held that, although section 133 of the BNA Act, 1867, sets a minimum standard as to the use of languages which "may not be diminished by the Parliament of Canada,"22 the section does not preclude "the conferring of additional rights or privileges or the imposing of additional obligations respecting the use of English and French, if done in relation to matters within the competence of the enacting Legislature."23 The Official Languages Act was justified by the Court as within the ambit of federal power over criminal procedure at section 91(27), federal courts at section 101, and federal institutions, on the basis of the peace, order, and good government power of section $91 .^{24}$

The Court also declared that section $91(1),{ }^{25}$ which conferred on Parliament the right to amend the Constitution of Canada except "as regards the use of the

16. Can. Rev. Stat. app. III, § 5(3) (1970).

17. Id. at $\S 2(\mathrm{~g})$.

18. Can. Rev. Stat. ch. 0-2 (1970).

19. Id. at $\S 2$.

20. Id.

21. [1975] 2 S.C.R. 182.

22. Id. at 192 .

23. Id. at 192-93. Attorney Gen. of Quebec v. Blaikie, 101 D.L.R.3d 394 (1980), decided that the Quebec legislature could not diminish the language rights in section 133 of the BNA Act.

24. Jones, [1975] 2 S.C.R. at 191-92.

25. Repealed by Item 1 of the Schedule to the Constitution Act, 1982, ch. 11. 
English or French language," 26 was designed to maintain the language guarantees of section 133. It was not, however, a "general substantive limitation" which would prevent Parliament from extending the use of English and French beyond that which section 133 prescribed. ${ }^{27}$

\section{Manitoba and Language}

\section{A. Language of the Courts and of Government}

Since 1738, when the explorer La Vérendrye reached the site of what is now Winnipeg, there has been a French presence in the Province of Manitoba. Indeed, when Manitoba entered Confederation in 1870, there were more French- than English-speaking citizens. ${ }^{28}$ Fearing a massive influx of English settlers from Ontario, delegates sent by the Riel provisional government to Ottawa carried with them a mandate to negotiate a constitutional guarantee of language rights for French-speaking Manitobans. These negotiations resulted in the inclusion of section 23 in the Manitoba Act, 1870. ${ }^{29}$ This section is virtually identical to section 133 of the BNA Act. ${ }^{30}$

Due to uncertainty about the legislative competence of Parliament to enact the Manitoba Act, it was subsequently ratified by the Imperial Parliament of the United Kingdom in 1871.31 Accordingly, as then supposed, the language rights secured by section 23 became constitutionally protected, and neither the Manitoba Legislature nor the Canadian Parliament could nullify or alter them.

In 1890, when the English-speaking citizens of Manitoba were in the majority, the Manitoba legislature adopted The Official Language Act $^{32}$ which abrogated section 23 of The Manitoba Act, 1870. ${ }^{33}$ The Official Language Act provided that "the English language only shall be used in the records and journals of the Legislative Assembly of Manitoba, and in any pleading or process in or issuing from any court in the Province of Manitoba . . . [and] [t]he Acts of the Legislature of Manitoba need be printed and published only in the English Language."34

The Official Language Act was not contested until 1909, when the St. Boniface County Court ${ }^{35}$ ruled the Act ultra vires. Nevertheless, the decision was unreported and ignored. In 1976, in Regina v. Forest, ${ }^{36}$ the same Court again declared the Official Language Act unconstitutional. In response to Crown counsel's request that the Court pay heed to the serious consequences of such a finding, Judge Dureault quoted Lord Mansfield: "The constitution does not allow reasons of

\footnotetext{
26. Jones, [1975] 2 S.C.R. at 196.

27. Id.

28. W. Morton, Manitoba: A History 145 (1961).

29. Can. Rev. Stat. app. II No. 8 (1970).

30. Compare section 23 of the Manitoba Act, 1870, CAN. REv. STAT. app. II No. 8 (1970), with section 133 of the BNA Act, CAN. REV. STAT. app. II No. 5 (1970).

31. BNA Act, 1871, 34 \& 35 Vict., ch. 28, § 5 (U.K.); CAN. Rev. STAT. app. II No. 11 (1970).

32. Man. Rev. Stat. ch. 0-10 (1970).

33. Manitoba Act, Can. Rev. Stat. app. II No. 8 (1970).

34. Man. Rev. Stat. ch. 0-10 (1970).

35. Bertrand v. Dussault \& Lavoie, 1909, at last reported in Re Forest \& Registrar of Court of Appeal of Manitoba, 77 D.L.R.3d 445, 458 (1977).

36. 74 D.L.R.3d 704 (1977).
} 
State to influence our judgments: God forbid it should! We must not regard political consequences, how formidable soever they might be: if rebellion was the certain consequence, we are bound to say 'fiat justitia, ruat caelum'. [Let justice be done even though the Heavens may fall] . . . ."37

This decision was also ignored. In what Mr. Justice Monnin of the Manitoba Court of Appeal called an "arrogant abuse of authority," the Attorney-General of Manitoba announced that "the Crown [would] not accept the ruling of the Court with respect to the constitutionality of the Official Language Act . . . ."38

On appeal, the Manitoba Court of Appeal ruled that the Legislature of Manitoba could not unilaterally amend section 23 of the Manitoba Act. In support of the holding, Chief Justice Freidman, speaking for the court stated:

\begin{abstract}
To say that Manitoba could on its own diminish rights conferred by s. 23 would be to negate the very reason for the enactment of that section in the first place. History supports the view that s.23, like s.22 on denominational school rights, was intended to be a protection for minorities in Manitoba against the possible ill will of the majority. The Frenchspeaking citizens of Manitoba, including not only the famous Louis Riel but all the representatives of the French-speaking parishes . . . were induced to put an end to the Red River Insurrection and to support the creation of a Province and its union with Canada only on the basis that their rights would be ensured for the future. The enactment of the Official Language Act deprived them of the linguistic rights which were safeguarded, or thought to be safeguarded, under s.23. ${ }^{39}$
\end{abstract}

Although the Chief Justice spoke of linguistic rights secured by section 23, he was unwilling to give effect to all of them, particularly the requirements that the records, journals, and statutes of the legislature be in both languages. Accordingly, the Chief Justice stated that he was not prepared "to declare that all of the statutes of Manitoba since 1890 . . . [were] constitutionally invalid."40

The Court was reluctant to declare all of the statutes of Manitoba unconstitutional for two reasons. First, since the Court itself "was established by a statute enacted wholly in English after 1890, it could hardly be that we could make any declaration at all if the statute providing for our existence were not valid." 41 In effect, such a declaration would require the Court to create its own jurisdictional mandate. Second, the Court refused to countenance the proposition that a failure to comply with the provisions of section 23 "has the effect of rendering the statutes invalid." 42 The Court noted that "British law draws a clear distinction between directory and mandatory statutes, and a further distinction between those mandatory statutes that result in nullities and those mandatory statutes that result in irregularities." 43

Even though unwilling to declare the whole of the Official Language Act ultra vires, the Court did make a declaration that "the Official Language Act is inoperative in so far as it abrogates the right to use the French language in the Courts of

37. Id. at 717

38. Re Forest, 77 D.L.R.3d at 458.

39. Forest v. Attorney Gen. of Manitoba, 98 D.L.R.3d 405, 421 (1980).

40. Id. at 423

41. Id.

42. Id.

43. Id. 
Manitoba, as conferred by s.23 of the Manitoba Act, 1870, confirmed by the British North America Act, 1871." "44

On appeal to the Supreme Court of Canada, the issue was fixed by order of the Chief Justice which may be paraphrased as follows: "Are the provisions of the [Official Language Act] . . . or any of those provisions, ultra vires or inoperative in so far as they abrogate the provisions of s.23 of the Manitoba Act, 1870? . . ."45

Once again, a narrow ruling was given. The Court did not answer the question directly, but dismissed the appeal, noting that Manitoba has no more power to amend section 23 of the Manitoba Act than Quebec has to amend section 133 of the BNA Act. ${ }^{46}$

Thus, the validity of Manitoba's post-1890 statute law remained uncertain. In Regina $v$. Bilodeau, ${ }^{47}$ the defendant was charged with speeding under the Highway Traffic Act, and was issued a summons to appear in court pursuant to the Summary Convictions Act. The accused brought a motion for dismissal of the proceedings on the grounds that the statutes under which he was charged were invalid or inoperative because they had been printed in the English language only, contrary to section 23 of the Manitoba Act, 1870. The motion was dismissed by the Manitoba Provincial Court, and the accused was subsequently convicted of the charge.

An appeal from the conviction was dismissed by the Manitoba Court of Appeal. The Court, after commenting on the widespread chaos and social disorder that would result from a declaration that Manitoba's statutes were invalid, held that "the language requirements of section 23 are directory only, and not mandatory." 48 The Court also noted that if indeed the statutes were invalid, it would lack the authority to make such a declaration. ${ }^{49}$

The dissent, however, argued that language rights secured by section 23 were constitutionally entrenched, and could not be challenged "by the application of the principles of directory versus mandatory legislation." 50 In dissenting in part, Justice Monnin persuasively argued that,

[E]ntrenched linguistic rights are by nature mandatory and never directory. If they were directory only, the risk is that they would never be enjoyed or be of any use to those to whom they were addressed. If it were merely directory it would fly in the fact of entrenchment, which by its very nature, is mandatory. The authorities submitted by counsel on the mandatory or directory nature of legislation has [sic] no application to entrenched rights.

Violence to the constitution cannot be tolerated. ${ }^{51}$

An appeal to the Supreme Court, which was to have been heard in May of 1983, was withdrawn due to a momentous agreement announced on May 16, 1983

44. Id. at 424 .

45. [1979] 2 S.C.R. 1032, 1035.

46. Id. at 1039. As a result of this decision the Official Language Act, 1890, MAN. Rev. STAT. ch. 010 (1970), was repealed by An Act Respecting the Operation of Section 23 of the Manitoba Act in Regard to Statutes, chs. $3 \&$ 7, 1980 Man. Stat. 11.

47. [1981] 1 W.W.R. 474.

48. Bilodeau v. Attorney General of Manitoba, [1981] 5 W.W.R. 393, 402.

49. Id. at 401 .

50. Id. at 407 .

51. Id. at $406-07$. 
by Prime Minister Trudeau. ${ }^{52}$ The accord, involving Manitoba, Ottawa and the Société franco-manitobaine, was reached after a year of closed meetings, and is in the form of a proposed constitutional amendment whereby Manitoba will join New Brunswick in giving official recognition to the French language. ${ }^{53}$ As of January 1, 1987, French and English will be the official languages of the courts and the Legislature in Manitoba, just as they were in 1870 when Manitoba joined Confederation. In addition, services in French will be available at the head offices of all government departments, agencies, and Crown corporations. As of January 1, 1986, all new regulations will be in both languages. All new laws will be adopted and published in both languages after January 1, 1987. The Manitoba government will have ten years to translate all of the statutes passed since 1890 , when the use of French was abolished. Thus, it appears that the rights of the Franco-Manitobans after having been denied for so many years, will at last be vindicated.

\section{B. Language of Education-Manitoba}

In 1890, the School Acts ${ }^{54}$ were passed in Manitoba which replaced the existing system of separate denominational schools with a unitary public school system supported by public taxes. This jeopardized the use of French as a language of instruction since French schools had been Roman Catholic. This legislation generated much controversy and was, therefore, immediately challenged in the courts. In City of Winnipeg v. Barrett, ${ }^{55}$ the plaintiffs maintained that the new legislation contravened section 22 of the Manitoba Act, 1870, which is similar to section 93 of the BNA Act, 1867, and provides that "the . . . legislature may exclusively make laws in relation to education... . [so long as] [n]othing in any such law shall prejudicially affect any right or privilege with respect to denominational schools which any class of persons have by law or practice in the province at the Union." 56

The plaintiffs argued that they were in a less favorable position than those who could take advantage of free public education in that, although taxed to support public schools, the plaintiffs also bore the additional burden of supporting their own separate religious schools. The Privy Council upheld the constitutional validity of the School Acts. In addition, the Court emphasized the existence and consequences of freedom of choice in attending a sectarian or nonsectarian school, when it remarked that,

Roman Catholics and members of every other religious body in Manitoba are free to establish schools throughout the province; they are free to maintain their schools by school fees or voluntary subscriptions . . . . No child is compelled to attend a public school. No special advantage other than the advantage of a free education in schools conducted under public management is held out to those who do attend... [w]hat right or privilege is violated or prejudicially affected by the law? . . It is owing to religious convictions which

52. Manitoba Saved from Illegal Laws, Pawley Confums, Toronto Globe \& Mail, May 19, 1983, at 5.

53. Afer 93 Years, a Reason to Cheer, Toronto Globe \& Mail, May 26, 1983, at 2.

54. An Act Respecting the Department of Education, ch. 37, 1890 Man. Stat. 175; The Public Schools Act, ch. 38, 1890 Man. Stat. 179.

55. [1892] A.C. 445.

56. CAN. Rev. Stat. app. II No. 5, § 93 (1970). 
everybody must respect, and to the teaching of their Church, that Roman Catholics and members of the Church of England find themselves unable to partake of advantages which the law offers to all alike. ${ }^{57}$

The harshness of this decision was tempered in Brophy v. Attomey General of Manitoba, ${ }^{58}$ where the Privy Council continued to uphold the validity of the Acts, but ruled that the legislation adversely affected the rights and privileges of the Roman Catholic minority in relation to education, specifically the right to have their schools maintained out of the general taxation of the province. Consonant with section 22(2) of the Manitoba Act, the Privy Council decided that the plaintiffs were entitled to appeal to the Governor-General in Council for remedial orders. ${ }^{59}$

In 1896, the historic Greenway-Laurier ${ }^{60}$ compromise was reached on the school question. An amendment to the Public Schools Act ${ }^{61}$ provided that in any school in towns and cities where the average attendance of Roman Catholics was forty or more (in rural districts twenty-five and more), the trustees, when petitioned by the parents of such children, were required to employ at least one Roman Catholic teacher in such a school. The amendment also permitted Francophones of Manitoba to receive their school instruction in French: "[w]hen ten of the pupils in any school speak the French language, or any language other than English, as their native language, the teaching of such pupils shall be conducted in French, or such other language, and English upon the bi-lingual system."62

In 1916, however, the Francophones of Manitoba were dealt a stinging blow when the right to instruction in the French language was abolished. ${ }^{63}$ The absence of the French language in the school system remained the status quo until 1966, when an amendment to the Public Schools Act ${ }^{64}$ re-established French as a language of instruction for a period not to exceed fifty percent of the teaching day.

In 1970, the Public Schools Act was amended once again, and French language education was accorded a status it had not enjoyed since before 1916. In fact, for the first time in Manitoba's legislative history, both French and English were expressly declared to be "the languages of instruction in public schools." 65 A school board is required by section $258(8)$ to provide instruction in French if the parents of twenty-eight or more pupils in an elementary grade or twenty-three or more pupils in a secondary grade so request. According to section 258(9), however, the Minister of Education may, at his discretion, require a school board to set up classes for fewer students.

It is noteworthy that "mother tongue" is not a criterion for French language instruction in Manitoba; rather, the criterion is the number of students whose parents request instruction in French. This has had the effect of creating a heavy

57. City of Winnipeg, [1892] A.C. at 457-58.

58. [1895] A.C. 202.

59. Id. at 228.

60. R. BROWN \& R. COOK, CANADA 1896-1921, at 12-17 (1974).

61. An Act to Amend the Public Schools Act, ch. $26 \S 4,1897$ Man. Stat. 99.

62. Id. at $\S 10$.

63. An Act to Further Amend the Public Schools Act, ch. 88, 1916 Man. Stat. 193.

64. An Act to Amend the Public Schools Act (2), ch. 49, 1966-67 Man. Stat. 247.

65. An Act to Amend the Public Schools Act (2), ch. $60 \S 258,1970$ Man. Stat. 597. 
demand for French second-language immersion programs for Anglophone students. In the years between 1976 and 1981, the number of students enrolled in French immersion programs in Manitoba more than tripled. ${ }^{66}$

\section{NeW BRUNSWICK}

\section{A. The Population}

The province of New Brunswick joined the Canadian Confederation in 1867 and soon developed a large French-speaking population. As is well known, New Brunswick now has a higher percentage of people belonging to a linguistic minority than any other Canadian province. In 1976, thirty-three percent of the population claimed French as their mother tongue. ${ }^{67}$ The magnitude of this minority has been a distinctive feature of New Brunswick's political climate.

\section{B. Official Languages of New Brunswick Act}

No particular protection was given to the French language until 1969 when the provincial legislature, following the lead of the federal government, enacted the Official Languages of New Brunswick Act. ${ }^{68} \mathrm{Few}$ of the new Act's provisions were put into effect, however, until the late 1970's.

Section 2 of the Act declares the equality of status of French and English as follows: "[T]he English and French languages are the official languages of New Brunswick for all purposes to which the authority of the Legislature of New Brunswick extends, and possess and enjoy equality of status and enjoy equal rights and privileges as to their use for such purposes." 69 The remaining sections prescribe the specific ways in which language rights are to be protected. In any proceeding of the legislature or its committees, either of the official languages may be used.70 In the printing of legislative records, reports, ${ }^{71}$ bills, ${ }^{72}$ and statutes ${ }^{73}$ use of both official languages is mandatory. All notices and documents published by the government, its agencies, and Crown corporations are to be printed in both languages, subject to regulation. ${ }^{74}$

Individuals have the right, subject to regulation, to communicate with and obtain services from the government in either of the official languages. ${ }^{75}$ Also, subject to regulation, individuals have the right to be heard in court proceedings in the official language of their choice. ${ }^{76}$ Under the sound discretion of the court, the judicial proceedings may be conducted totally or partially in one of the official

66. 1981 Comm'r of Official Languages AnN. Rep. 199.

67. Council of Ministers of Education, The State of Minority Language Education in the Ten Provinces of Canada 176 (1978) [hereinafter Minority Language Education Report].

68. N.B. REv. StaT. CH. 0-1 (1973)

69. Id. at $\S 2$.

70. Id. at $\S 3$.

71. Id. at $\S 4$

72. Id. at $\S 5$.

73. Id. at $\S \S 6 \& 7$.

74. Id. at $\S 8$.

75. Id. at $\S 10$.

76. Id. at $\S 13(1)$. 
languages if so requested by any party. ${ }^{77}$

As to the language of education, section 12 specifically provides:

In any public, trade or technical school

(a) where the mother tongue of the pupils is English, the chief language of instruction is to be English and the second language is to be French;

(b) where the mother tongue of the pupils is French, the chief language of instruction is to be French and the second language is to be English;

(c) subject to paragraph (d), where the mother tongue of the pupils is in some cases English and in some cases French, classes are to be so arranged that the chief language of instruction is the mother tongue of each group with the other official language the second language for those groups; and

(d) where the Minister of Education decides that it is not feasible by reason of numbers to abide by the terms of paragraph (c), he may make alternative arrangements to carry out the spirit of this Act. ${ }^{78}$

The Act, nevertheless, fails to determine the language of instruction for immigrants whose mother tongue is neither French nor English. There may be situations where immigrants may not have the right to choose the language of instruction. For example, if Italian pupils were living in an area where the mother tongue of other pupils was exclusively French, then section 12(c) would not apply, and according to section 12(b) French would be the chief language of instruction. ${ }^{79}$

\section{Equality of Two Linguistic Communities Act}

In 1981, the Equality of Two Linguistic Communities Act ${ }^{80}$ was adopted by the Legislative Assembly of New Brunswick. The Act officially recognizes the existence and equality of the French and English linguistic communities within New Brunswick. ${ }^{81}$ The Act also encourages the development of the two linguistic communities by providing that " $[t]$ he Government of New Brunswick shall ensure protection of the equality of status and the equal rights and privileges of the official linguistic communities and . . . their right to distinct institutions within which cultural, educational and social activities may be carried on."82 To this end, the Act requires the Government of New Brunswick to "take positive actions to promote the cultural, economic, educational and social development of the official linguistic communities."83

\section{Canadian Charter of Rights and Freedoms}

In 1981, New Brunswick was the only Canadian province to agree to the enshrinement of language rights in respect to government and the courts in the new Canadian Charter of Rights and Freedoms. ${ }^{84}$ These rights are identical to

\footnotetext{
77. Id. at $\$ 13(2)$.

78. Id. at $\$ 12$.

79. Id.

80. Ch. 0-1.1, 1981 N.B. Stat. 1.

81. Id. at $\S 1$.

82. Id. at $\S 2$.

83. Id. at $\S 3$.

84. Part I of the Constitution Act, 1982, which is Schedule B of the Canada Act 1982, 1982, ch. 11
} (U.K.). 
those imposed on the federal government and federal courts by the Charter. The Charter establishes that (1) English and French are the official languages of New Brunswick and each has equal status, rights, and privileges in respect to all institutions of the government of New Brunswick, ${ }^{85}$ (2) each individual has the right to use either English or French in any debates or other proceedings of the legislature of New Brunswick, ${ }^{86}$ (3) the statutes, records, and journals of the legislature of New Brunswick shall be published in English and French with each version having equal authority, ${ }^{87}$ (4) English or French may be used in any pleading or process issuing from a New Brunswick court, ${ }^{88}$ and (5) any member of the public has the right to communicate with, or receive available services from, the government or legislature of New Brunswick in English or French. ${ }^{89}$ The foregoing rights are similar to those provided by the Official Languages of New Brunswick Act, ${ }^{90}$ except that the guarantees provided by sections 19(2) and 20(2) of the Charter are now absolute and no longer subject to regulation.

\section{ONTARIO}

\section{A. Language of the Courts and of Govermment}

Ontario has a larger Francophone minority in terms of numbers than any other Canadian province. In 1976, over 460,000 residents of Ontario claimed French as their mother tongue, more than double the number of Francophones in the next closest province-New Brunswick. ${ }^{91}$ Ontario's Francophones, however, represent only $5.6 \%$ of its total population, compared to $33 \%$ in New Brunswick. ${ }^{92}$ Unlike Quebec, Ontario was not bound by section 133 of the BNA Act, 1867. Accordingly, its legislative and judicial institutions have remained unilingually English until recently.

In 1897, legislation was passed which formally recognized the existing practice regarding the language of the courts. Section 1 of An Act Respecting the Administration of Justice ${ }^{93}$ made English the exclusive language of the courts by stipulating that "[a]ll writs, pleadings and proceedings in any court of justice within Ontario, shall be in the English language only." This provision was consolidated as part of the Judicature Act in $1914,{ }^{94}$ and it is still in force. It is now, however, subject to a modification. In 1978, the Judicature Act was amended to give the French language legal recognition in designated courts in certain counties and districts of Ontario. ${ }^{95}$ Under section 130(4) of the Act, such courts, upon application of a party who speaks French, must direct that "the hearing in the proceeding be

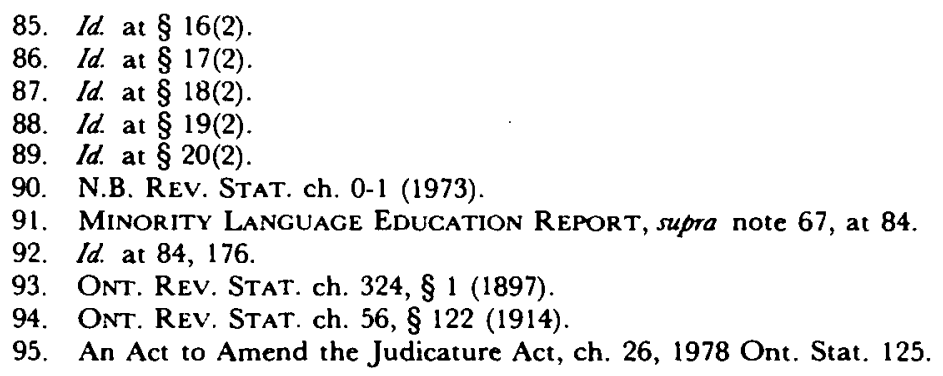


conducted before a judge who speaks both the English and French languages or, where there is a jury, before a judge and jury who speak both the English and French languages."96 Furthermore, where an application and direction has been made under section 130(4), the court may direct "that the hearing or any part of the hearing be in the French language if, in the opinion of the court, the hearing or part can be so conducted effectually."97

In accordance with section 130(7), evidence given in French "in a proceeding in respect of which a direction is made . . . shall be received and recorded in the French language and shall be transcribed in that language for all purposes."98 Additionally, section $130(8)$ permits any document filed by a party in a proceeding in a small claims court in any of the designated counties or districts to be in French.

There are no statutory requirements in Ontario pertaining to the use of English or French in the debates and records of the legislature. Notwithstanding the almost exclusive use of English, resort to the English language is not mandatory according to the rules of the House. This option was recently mentioned by Ontario's Premier Davis in a letter to four Members of Parliament from Quebec. ${ }^{99}$ Since Confederation, the statutes of Ontario have been enacted, printed, and published exclusively in the English language. At present, some 150 of the province's most important statutes have been translated into French, but they have no official legal status. They are, however, admissible in court as evidence "to prove the contents thereof but, in the event of a conflict between the version published under the Statutes Act . . . and the French language translation, the version published under the Statutes Act shall prevail." 100

\section{B. Education}

At the time of Confederation, the primary issue in respect to education was religion, involving language only indirectly. The Roman Catholic minority of Ontario and the Protestant minority of Quebec wished to maintain separate denominational schools and to have the rights to the establishment and preservation of such schools guaranteed by the constitution. This was accomplished by section 93 of the BNA Act, 1867.

By the turn of the century, the primary issue in education shifted from religion to language. Denominational schools, which initially had been a matter of local responsibility, became increasingly subject to provincial supervision as education reforms were instituted to promote more centralized and uniform school systems. In Ontario, this led to attempts to regulate the use of French as a language of instruction in the Roman Catholic schools. Regulations were first introduced in

96. Ont. Rev. Stat. ch. 223, § 130(4) (1980).

97. Id. at $\S 130(\mathrm{G})(\mathrm{a})$.

98. Id. at $\$ 130(7)$.

99. "In accordance with the rules of the House, members of the Legislature may address the House in French or English and his or her remarks recorded in the Debates in the language they were delivered [sic]." Letter from Premier William Davis to Céline Hervieux-Payette, David Berger, Eva Côté and JeanClaude Malepart (Jan. 16, 1981).

100. Evidence Act, ONT. Rev. Stat. ch. 145, § 25(2) (1980). 
1885, culminating in the infamous regulation 17 of 1913.101 This regulation severely curtailed the use of French in Catholic schools and provoked bitter controversy among French Canadians. They denounced it as a "deliberate and obvious policy of assimilation." 102 The regulation was supported by Irish Catholics who feared that the continued use of French in the schools would jeopardize the status of the separate schools in the province. Regulation 17 was contested in several cases, ${ }^{103}$ most notably Trustees of the Roman Catholic Separate Schools of Ottawa $v$. MacKell, ${ }^{104}$ as being an infringement upon the rights and privileges guaranteed to the denominational schools by section 93 of the BNA Act, 1867. In MacKell, the regulation was upheld by the Privy Council, which ruled that "the class of persons to whom the right or privilege is reserved must . . . be a class of persons determined according to religious belief, and not according to race or language."'105

The status of the French language in Ontario schools remained virtually unaltered for the next fifty years until ferment and change in Quebec stimulated Francophone Ontarians to become more cognizant of their rights and aspirations. Furthermore, certain government leaders in Ontario began to recognize the historic linguistic arrogance of the large English majority and consequent ill-treatment of Ontario's French population.

The year 1968 was a breakthrough period for French-language education in Ontario. Following the recommendations of the Beriault Commission, the government adopted legislation which transformed what had been toleration of clandestine French education into full-fledged legal recognition. An amendment ${ }^{106}$ to the Schools Administration Act required a school board to "provide for the use of the French language in instruction" when requested by the parents of at least thirty French-speaking pupils at the elementary level. Non-Francophones were also permitted to enroll in French language classes or schools if "the principal is satisfied that the attendance of such pupils will not delay the progress of the Frenchspeaking pupils."107

In 1968, and for the first time in Ontario's history, French was provided as a language of instruction in secondary schools. An amendment to the Secondary Schools and Boards of Education Act required a school board to "provide for the use of the French language in instruction" when twenty or more students elected to be taught in French, and could be assembled in classes of twenty or more. ${ }^{108}$

101. 32 Ont. L.R. 252-54 (1917).

102. 2 Royal Commission on Bilingualism and Biculturism, Report 51.

103. See e.g., McDonald v. Lancaster Separate School Trustees, 31 Ont. L.R. 360 (1914), affd, 24 D.L.R. 868 (1915); Trustees of the Roman Catholic Separate Schools for Ottawa v. Ottawa Corp., [1917] A.C. 76.

104. [1917] A.C. 62.

105. Id. at 69.

106. An Act to Amend the Secondary Schools Administration Act, ch. $121 \S 9,1968$ Ont. Stat. 536 (amending Schools Administration Act, ONT. REV. STAT. ch. 361, § 35 (1960)).

107. Id.

108. An Act to Amend the Secondary Schools and Boards of Education Act, ch. 122, § 10, 1968 Ont. Stat. 547 (adding $\$ 113(\mathrm{a})(2)$ to the Secondary Schools and Boards of Education Act, ONT. REV. STAT. ch. $362(1960))$. 
In 1974 , the 1968 provisions were carried forward and consolidated, with some modifications, into the Education Act. ${ }^{109}$ The provisions with respect to language comprise part XI entitled "French Language Instruction." The important and relevant changes are that:

(1) It is no longer the parents, but the pupils themselves who must elect to have instruction in French. Classes wil be set up if as few as 25 pupils can be assembled for such purpose. ${ }^{110}$

(2) English-speaking pupils, at the request of a parent or guardian, may attend French schools if approved by a majority vote of an admissions committee. ${ }^{111}$

The response to Ontario's language legislation has been impressive. In the school year 1979-80, there were over 69,000 students enrolled in French-language elementary schols or instructional units, and over 29,000 at the secondary level. ${ }^{112}$ Equally impressive, in 1980-81 over 17,000 were enrolled in French immersion programs. $^{113}$

The future of French-language teaching in Ontario seems assured. The Education Act now permits French-speaking ratepayers to elect members of a French Language Advisory Committee to a school board. Since teaching in French is now guaranteed, the issue for the future is whether Francophones will obtain the right to have their own schools and their own school boards. Manifestly, Ontario has come a long way towards the recognition and toleration of its French minority's right to exercise their linguistic and educational preferences. Nonetheless, the road is long and difficult, and the battle continues.

\section{Personal Diary-Quebec}

\section{A. The Bye-Election in Notre-Dame-de-Grâce 1968, and Bill 85}

In the fall of 1968 I was the Liberal candidate for the Quebec National Assembly in the Montreal constituency of Notre-Dame-de-Grâce (N.D.G.). During the campaign, Premier Jean-Jacques Bertrand of the Union Nationale promised the electorate of N.D.G. that they would have the freedom to choose whether their children would be educated in English or French. This promise was intended to appease the Italian immigrants of St.-Léonard, who were bitter over a decision by the trustees of the St.-Léonard School Commission to substitute unilingual French classes for bilingual classes. As a result of this decision and concomitant linguistic fervor, the language crisis in St.-Léonard became the main issue in the byeelection.

Despite Bertrand's campaign promise I received eighty percent of the ballots cast. Following the election, Premier Bertrand fulfilled his campaign promise when he personally presented Bill $85^{114}$ in the National Assembly on December 9, 1968. It was designed to "préciser le rôle de la langue française dans le domaine de

109. ONT. REv. STAT. ch. 129 (1980).

110. Id. at $\S 258(2)$.

111. Id. at $\S 258(6)$.

112. COMM'R OF Official LANGUages, supra note 66.

113. Id.

114. An Act to Amend the Education Department Act, The Superior Council of Education Act and The Education Act. 
l'éducation au Québec."115 The Bill sought to protect minority language rights by giving parents freedom of choice with respect to the language of instruction for their children. At the same time, the proposed Bill aimed to secure the position of the majority by requiring all students to have a working knowledge of French.

When the Bill was sent to committee, it became the subject of impassioned public debate. In general, Anglophones were supportive of the Bill; however, many Francophone nationalists denounced the principle of freedom of choice on the grounds that it would further imperil the status of the French language in Quebec. Undoubtedly, the Francophone concern and opposition against the Bill were not completely unwarranted. A rapidly declining birth-rate among Francophones combined with an overwhelming tendency of immigrants to voluntarily undergo integration with the English minority posed a serious threat to the French community. Since English was the language of upward mobility, even many French Canadians sent their children to English schools. Although over eighty percent of Quebec's population was Francophone, English was largely the language of work and business-especially in Montreal. Francophones argued that this linguistic domination was the consequence of economic domination by the English minority. And undeniably, the upper echelons of business and management were disproportionately occupied by Anglophones.

Four months after the introduction of Bill 85, it was withdrawn, much to the embarrassment of the government. It was, Premier Bertrand announced, "un bébé que personne ne veut."116 He remained, however, committed to the principle of freedom of choice. Throughout the summer of 1969, the St.-Léonard situation became progressively worse, culminating in the riots of September 10th when French unilingualists and Italian immigrants clashed. This violent confrontation underscored the need to define language rights across the province.

\section{B. Bill 63. An Act to Promote the French Language in Quebec}

In October of 1969, after winning a leadership campaign against Education Minister Jean-Guy Cardinal, Premier Bertrand forced Cardinal to present Bill 63. According to Cardinal, the purpose of the bill was:

\footnotetext{
d'assurer que les enfants de langue anglaise du Québec acquièrent une connaissance d'usage de la langue française et que les personnes qui s'établissent au Québec acquièrent la connaissance de la langue française et fassent instruire leurs enfants dans cette langue. Il confirme en outre la possibilité pour les parents de choisir entre le français et l'anglais, la langue dans laquelle les cours seront donnés à leurs enfants. ${ }^{117}$
}

The principal provisions of Bill 63 included:

115. Id. (taken from the "Explanation Notes" to Bill 85) (Translation: "to define the role of the French language within the realm of education in Quebec.")

116. Le Devoir, Mar. 20, 1969 cited by Macdonald, In Search of A Language Policy: Francophone Reactions to Bills 85 and 63, in Quebec's Language Policies: Background and Response 227 (J. Mallea ed. 1977). (Translation: "a baby whom no one wanted.")

117. Explanatory Notes to Bill 62. (Translation: to ensure that the English-speaking children of Quebec acquire a working knowledge of the French language and that persons who settle in Quebec may acquire the knowledge of the French language and have their children instructed in such language. It also confirms the parents' option to choose either French or English as the language in which courses will be given to their children.) 
1. Amending the Education Department Act . . . [by adding:] The Minister shall take the measures necessary to . . . ensure a working knowledge of the French language to children to whom instruction is given in the English language."118

2. Amending [section 203 of] the Education Act. . . To take the measures necessary to have the courses of study . . . adopted or recognized for Catholic, Protestant or other public schools . . . given to all the children domiciled in the territory under their jurisdiction... . Such courses must be given in the French language. They shall be given in the English language to any child for whom his parents or the persons acting in their stead so request . . . . [T]he curricula and examinations must ensure a working knowledge of the French language to such children ... 119

3. Amending [section 3 of] the Immigration Department Act [by adding:]

[t]ake the measures necessary so that the persons who settle in Quebec may acquire the knowledge of the French language . . . and may have their children instructed in educational institutions where courses are given in the French language. ${ }^{120}$

We Liberals added the proviso in section 1, supra, that all English-speaking children had to be properly instructed in the French language. It was this article that caused the Protestant School Board of Greater Montreal (P.S.B.G.M.) and the body which it controlled, the Quebec Association of Protestant School Boards, to oppose Bill 63. The P.S.B.G.M. maintained that it could not and should not be forced to teach French, and particularly to teach in French, because it contended that the right to determine the language of instruction was a prerogative of the School Board, and not the legislature. For this reason, the P.S.B.G.M. had not supported the Italians in St.-Léonard. The argument of the P.S.B.G.M. was that insofar as the legislature was clearly without legal authority to force it to teach in French, it necessarily followed that the School Board of St.-Léonard could not be compelled to give instruction in English to the Italian Canadians.

Francophone condemnation of Bill 63 was based primarily on the grounds that freedom of choice would facilitate the assimilation of new immigrants into the English minority. The ultra-nationalist Société Saint-Jean-Baptiste de Montréal called the bill a fundamental capitulation. ${ }^{121}$ In words of remarkable foresight, René Levesque, who had resigned from the Quebec Liberal Party, called for legislation that would (1) proclaim official French unilingualism, and (2) compel future immigrants to send their children to French schools. After a lengthy filibuster and many noisy demonstrations and protests, the legislation was nevertheless adopted and then assented to on November 28, 1969.

\section{Consumer and Corporate Language Legislation}

On April 29, 1970, the Liberal government of Robert Bourassa gained election by replacing the Union Nationale government of Jean-Jacques Bertrand. Very soon thereafter I became Minister of Revenue for five months and then the Minister of Financial Institutions, Companies and Cooperatives. The English-speaking population was concerned with the rising nationalism of French Canadians and in particular their desire to protect the French language. Maintaining the priority of the French language was our general theme, but priority also meant recognizing

118. Ch. 9, §1, 1969 Que. Stat. 61 (amending Que. Rev. Stat. ch. 233, § 2 (1964)).

119. Id. at $\S 2$ (amending QUE. REV. STAT. ch. 235, $\S 205$ (1964)).

120. Id. at $\S 3$ (amending QUE. REV. STAT. ch. $68, \S 3$ (1968)).

121. Macdonald, supra note 116 , at 231. 
the second language. In this respect, I was particularly aware of and concerned about the delicate dichotomy-protecting the French language in Englishspeaking North America and at the same time preserving the rights of English Quebecers.

In 1971, I had the opportunity to write the priority of the French language into a new consumer law. This was the first legislation in Quebec history to recognize such priority. The Consumer Protection Act required consumer contracts to be drawn up in French, unless the consumer chose to exercise his undiminished right to have the contract worded in English. ${ }^{122}$ This priority of French brought severe criticism from the English electorate in Quebec despite its fairness. On the other hand, French Canadians and even the Parti Québécois Official Opposition were satisfied with the compromise. The formula of French language priority along with recognition of the English language became the basic guide for Bill 22,123 and, in my view, is a reasonably equitable solution to Quebec's linguistic dilemma. The English of Quebec, probably fearing "the thin of the edge of the wedge," were nevertheless strongly opposed to it.

In 1973, I presented much the same formula in an amendment to the Companies Act, which stated that "[a] company shall be incorporated only under a French name or a name consisting of both a French and an English version."124 It was further stipulated that the company could use its French name, its English name, or its bilingual name. This, nevertheless, caused protests from the English in Quebec.

Since the new law did not apply retroactively, an attempt was made to persuade the 60,000 active existing Quebec corporations with solely English names to adopt a bilingual name. To accomplish this, the government offered amendment of their letters patent without charge and provided special forms for the process. Notices were sent to all these companies, but less than twenty-five complied. Without much hope, I then wrote a personal letter to the presidents of the 500 leading companies which induced only a few to add a French name. Finally, these companies were surveyed to determine why they had not acted and the reply was in effect that compliance was not in their best interests.

\section{Bill 22-The Official Language Act}

In 1973, the Bourassa government was reelected by an overwhelming margin, gaining 102 of the 110 seats in the National Assembly. On July 31, 1974, Bill 22, entitled the Official Language Act, was adopted by the government, despite opposition from both English and French Québécois. The preamble to the Act declared the purpose of the legislation:

the French language is a national heritage which the body politic is in duty to preserve, and it is incumbent upon the government of the province of Quebec to employ every means in its power to ensure the preeminence of that language and to promote its vigour and

122. Ch. $74, \S 4,1971$ Que. Stat. 603 .

123. The Official Language Act, ch. 6, 1974 Que. Stat. 53.

124. An Act to Amend the Companies Act, ch. 65, $\S 31,1973$ Que. Stat. 724. 
quality. ${ }^{125}$

To that end, the Act declared French to be the official language of Quebec. ${ }^{126}$ The remaining sections of the Act outlined the requirements for its use in public administration, ${ }^{127}$ public utilities and professional bodies, ${ }^{128}$ labour, ${ }^{129}$ business, ${ }^{130}$ and education. ${ }^{131}$ Generally, however, Bill 22 imposed only bilingualism with some priority given to the French language.

The English of Quebec opposed Bill 22 because they feared that this was only the beginning of change and that resistance to any such change was preferable to the risk involved in attempting to reach a final solution of Quebec's dilemma. They were also urged on by the P.S.B.G.M. ("Board") which wished to protect its position that "Protestant" in section 93 of the BNA Act meant "English." The Board had a long history of protecting the status quo including the failure to support the Italians of St.-Léonard who wanted English schooling in 1968. The Board did not support Bill 85 and publicly opposed Bill 63,132 because the Board feared that the Bill gave the government the right to insure that instruction to English students in French was possible.

The Board's essential position on education was enunciated in an opinion ${ }^{133}$ written by four leading Quebec lawyers who argued that a pre-Confederation law of $1861^{134}$ conferred on the Protestants and Roman Catholics of Montreal and Quebec City a legal right to determine whether their denominational schools would employ French or English as the language of instruction. Accordingly, they contended that this was a "right or privilege with respect to Denominational schools" that was protected by section 93 of the BNA Act. This opinion, based on what was at best a complicated and tenuous historical argument, was rejected in a decision handed down in April of 1976 by the Quebec Superior Court. ${ }^{135}$ The Court held that: "the restrictions imposed by s.93(1) on the exclusive power of the Province in matters of education apply to the denominational aspect of schools, but not to the language in which they function . . . ${ }^{136}$ Even if the opinion had been accepted by the court, the Board generated expectations that were destined to remain unfulfilled. The express language of section 93 of the BNA Act protects only "Denominational" and "Dissentient" schools. Majority (common) school boards, although they may be denominational in fact are not denominational in

125. Ch. 74, 1974 Que. Stat. 713.

126. Id. at $\S 1$.

127. Id. at $\$ \S 6-17$.

128. Id. at $\$ \$ 18-23$.

129. Id. at $\$ \S 24-29$.

130. Id. at $\$ \$ 30-39$.

131. Id. at $\$ \$ 40-44$.

132. An Act to Promote the French Language in Quebec, ch. 9, 1969 Que. Stat. 61.

133. Legal Committee on Constitutional Rights in the Field of Education in Quebec, Report to the Protestant School Board of Greater Montreal (Nov. 29, 1969) [hereinafter cited as Report to the P.S.B.G.M.].

134. Acte concernant l'allocation provinciale en faveur de l'éducation supérieure,-et les écoles normales et communes, Consolidated Statutes of Lower Canada, ch. 15 (1861).

135. Protestant School Bd. of Greater Montreal v. Minister of Educ. of Quebec, 83 D.L.R.3d 645 (1978).

136. Id at 655 (emphasis added). 
law and, therefore, are denied protection by section 93 . As the four authors of the Board opinion concede, "the legislature has full power to fix the language of instruction" in regard to majority school boards. ${ }^{137}$ This was never brought to the attention of the English Catholics of St.-Léonard nor the Protestants of Westmount, both of whom represented majority school boards and clamoured vigorously for the protection of "rights" which they did not in law possess.

The Board's position was misleading in another important respect. The opinion specifically stated "[i]t is obvious that an education system designed to protect the rights of Roman Catholics and Protestants provides little comfort for those that belong to neither denomination."138 The foregoing was never brought to the attention of Jews, Greek Orthodox, and others mistakenly led by the Board to believe that they had rights in law. The limitations of the Board opinion were never made clear to the public, especially to Home and School Associations who collected large sums of money to defend their "rights." The Board glossed over the opinion rendered by claiming that, in effect, the guarantee of "Protestant" education in section 93 of the BNA Act meant that English language education was an indisputable right guaranteed for all citizens throughout Quebec. Moreover, the English-speaking public was led to believe that English language rights existed in respect to contracts, public signs, corporate names, all business matters, and dealings with the government.

Bill 22 was finally adopted on July 31, 1974, after a long Parti-Québécois filibuster. Tempers cooled until the fall of 1975, when the school year began and some Italian-speaking children who could not speak English were refused admission to English schools. This prompted Anglophones to agitate for the abolition of Bill 22, and the situation soon became tense again.

\section{E. CFCF Petition}

The peak of the frenzy was reached when a petition was signed by nearly 600,000 Quebecers who paid fifty cents each to send a telegram to Ottawa and to Quebec. A campaign promoted by the Montreal English-speaking radio station CFCF initiated this petition:

We, the undersigned, Canadians in the Province of Quebec, urgently demand that you use the power vested in you by the electorate to abolish the (sic) Bill 22 and restore our fundamental rights as Canadians, to work and to educate our children in the language of our choice.

We feel Bill 22 violates and is in direct contravention of the Federal Government's clear and emphatic official stand on bilingualism.

The petitioners, however, disregarded the absence of any "fundamental rights as Canadians to work and educate [their] children in the language of [their] choice." At that time, these rights did not exist in law or practice in any province. In fact, Quebec provided more minority education and language rights than any Canadian province, particularly under Bill 22. As evidence of Quebec's relatively greater recognition and establishment of minority language rights, a statement of

137. REPORT TO THE P.S.B.G.M., supra note 133, at 22.

138. Id. at 62 . 
the Canadian government revealed that "the educational rights of the Englishspeaking minority in the province of Quebec have been, and still are, better respected and served than the rights of French-speaking minorities of comparable importance in the other provinces of Canada."139

The second paragraph of the petition ignored the fact that the federal government's language law ${ }^{140}$ only applied to federal agencies and institutions. Furthermore, the call for bilingualism in the second paragraph was not consistent with the first paragraph, which really was a call for double unilingualism. ${ }^{141}$.

\section{F. Contestation of Bill 22 (P.S.B.G.M. v. Ministry of Education)}

The validity of Bill 22 and the dispute over language rights with respect to education was finally resolved in Quebec Superior Court in April of 1976 in P.S.B.G.M. v. Minister of Education of Quebec. ${ }^{142}$ The Court held that " $\left.\mathrm{t}\right]$ here is nothing against the validity of the Act in question," 143 and that "the choice of the language in the field of education remains the prerogative of the Legislature." 144 The Court arrived at its decision by first discussing the text of the BNA Act, 1867. After considering in order sections 133, 93, and 91(1), the Court noted that:

In the face of a constitutional text which

(i) only clearly guarantees the use of a language in its legislative and judicial aspect;

(ii) only clearly confines itself, regarding schools, to the criterion of denomination;

(iii) distinguishes, in its exceptions to the power of amendment of Parliament, between the recognized rights regarding schools and the recognized rights regarding the use of English and French;

what can one conclude other than that the restrictions imposed by s.93(1) on the exclusive power of the Province in matters of education apply to the denominational aspect of schools, but not to the language in which they function? ${ }^{145}$

The same conclusion was reached by the Court after reviewing the case law under section 93, particularly Ottawa Separate Schools Trustees v. MacKell. ${ }^{146}$ The situation was similar in MacKell, except that the position of the respective language groups was reversed. In 1913, the Ontario Ministry of Education had issued a regulation restricting the use of French as the language of instruction for all schools, both public and private. Declaring the contested regulation intra vires, it was held by the Privy Council that with respect to section 93 "the class of persons to whom the right or privilege is reserved must . . . be a class of persons determined according to religious belief, and not according to race or language."147

139. Ministry of Supply and Services, A National Understanding Statement of The Government of Canada on the Official Languages Policy 70 (1977).

140. Official Languages Act, Can. ReV. Stat. ch. 2 (1970).

141. Double unilingualism is a term coined after a voter in N.D.G. complained to me about a teller in her local bank who could not speak to her in English. She said that she believed in bilingualism. By that she meant that she expected all public and commercial offices to be bilingual and thus able to speak to her in English and to others in French. She could not speak French and did not intend to learn. To me, bilingualism is the desire and ability to speak and work in two languages.

142. 83 D.L.R.3d 645 (1978).

143. Id. at 676 .

144. Id. at 657 .

145. Id. at 655 .

146. [1917] A.C. 62 .

147. Id. at 69 . 
In writing for the majority, Chief Justice Deschênes then reviewed the school legislation in force prior to Confederation in order to determine whether that legislation conferred on the denominational schools the legal right to determine the language of instruction. Even after conceding that section 65(2) of the $1861 \mathrm{Act}^{148}$ conferred on the commissioners and trustees the power "to regulate the course of studies to be followed in each school," the Court declared that the plaintiffs were "letting their imagination run away" in attempting to "read in it the implicit power to choose the language of education."149

Lastly, the Court considered the plaintiff's argument that the protection of the denomination of schools in section 93 carried with it the protection of the language of instruction:

\begin{abstract}
When the constitutional text was similar, did anyone think of serving the French culture of the Catholic minority of Manitoba, when the language question was underlying the religious conflict which was jeopardizing its right to denominational schools? And when the constitutional text was identical did anyone think of saving the French culture of the Catholic minority of Ontario, when the language question also jeopardized its system of denominational schools?

At each of these solemn moments in our history the Courts have distinguished between language and faith, between culture and religion; they have recognized constitutional guarantees to the denomination of schools only and never did they interpret the British North America Act, 1867 , as an instrument of the protection of the language or the culture of a particular group. ${ }^{150}$
\end{abstract}

An appeal from the decision was dismissed by the Quebec Court of Appeal on January 18, 1978, because the Official Language Act (Bill 22) ${ }^{151}$ was no longer law, having been superseded by the Charter of the French Language (Bill 101). ${ }^{152}$

\title{
VII The Parti Quebecois-Bill 101
}

\section{A. Bill 101}

On November 15, 1976, the Parti Québécois was elected and immediately took steps to draft a language bill which would provide for considerably more than the mere priority of the French language. ${ }^{153}$ To that end, Dr. Camille Laurin (then Minister of State for Cultural Development) presented a white paper entitled $L a$ Politique Québécoise de la Langue Française ${ }^{154}$ to the National Assembly in April of 1977. The paper outlined the principles upon which the government's new language policy would be based. First and foremost, it stated: "Au Québec, la langue

148. Consolidated Statutes of Lower Canada, ch. 15 (1861).

149. 83 D.L.R.3d 645, 670 (1978).

150. Id. at $672-73$.

151. The Official Language Act, ch. 6, 1974 Que. Stat. 53.

152. Charte de la langue française, ch. 5, 1977 Que. Stat. 55 (current version at QUE. REV. STAT. ch. C-11 (1977)).

153. In May 1976, I made arrangements to teach on the McGill Law Faculty and not to run again in the next election. I had planned to be a member of the Quebec National Assembly for at most six to eight years and for no more than three elections. I had also had a final falling out with Premier Robert Bourassa in September of 1976.

154. C. Laurin, La Politique Québécoise de la langue Française (deposited in the National Assembly on April 1, 1977). 
française n'est pas un simple mode d'expression mais un milieu de vie."155 As the white paper explained, "Les francophones du Québec n'ont jamais cru que leur langue puisse être dissociée du destin de la nation tout entière, de son économie comme de sa culture."156

The identification of the French language with a way of life in Quebec and, more particularly, with a distinct national culture, precluded acceptance of a policy of institutional bilingualism:

Ce que les francophones réclament n'a rien à voir avec les procédés de "traduction de l'anglais" que veulent garantir des politiques de bilinguisme. Il s'agit de protéger et de développer dans sa plénitude une culture originale: un mode d'être, de penser, d'écrire, de créer, de se réunir, d'établir des relations entre les groupes et les personnes, et même de conduire les affaires. ${ }^{157}$

Accordingly, the aim of the new language policy was clear. Far more than ensuring the priority of the French language, it was to give Quebec's institutions and its society "un caractère foncièrement français." 158

A second principle of the new language policy was to respect "les minorités, leurs langues, leurs cultures." 159 While Dr. Laurin insisted that French be the common language of Quebec (just as English is for the rest of North America), he nevertheless recognized the important contributions and essential vitality of the other cultures that constitute Quebec and the necessity of preserving them. This was particularly true for the English minority:

L'anglais, tout particulièrement, aura toujours une place importante au Québec. Non pas seulement, comme on le répète souvent, parce qu'il est le moyen de communication le plus répandu en Amérique du Nord, mais parce qu'il tient aussi à l'héritge culturel des Québécois. Cependant, dans un Québec vivant en français, il sera normal que les Québécois, quelle que soit leur origine ethnique et culturelle, puissent s'éxprimer en français, participer de plein droit à une société française, admettre que le français est ici la langue commune à tous. ${ }^{160}$

That Anglophones living in Quebec should be capable of expressing themselves in French was, according to Laurin, something that good manners should have taken care of long ago. ${ }^{161}$

After heated public hearings and protracted debates, the Parti Québécois kept

155. Id. at 19. (Translation: "In Quebec, the French language is not simply a means of expression but a social environment.')

156. Id. at 1. (Translation: "French Quebecers have always held their language to be an inherent part of the destiny of the whole nation, of its economy as well as its culture.")

157. Id. at 21. (Translation: "What Francophones are demanding has nothing to do with the process of 'translating from English,' which the policies of bilingualism are meant to guarantee. The issue here is the protection and the full development of an original culture, a way of being, thinking, writing, creating, meeting, establishing relations with other groups or individuals, and even of conducting business.')

158. Id at 17. (Translation: "a fundamentally French character.")

159. Id. at 22. (Translation: "the minorities, their languages, their cultures.")

160. Id at 23. (Translation: "The English language, in particular, will always play an important role in Quebec. Not only, as is often said, because it is the most widely used means of communication in North America, but also because it is part of the cultural legacy of Quebecers. However, in a Quebec living in French, all Quebecers, regardless of their ethnic and cultural origin, will naturally express themselves in French, participate by right in a French society, and recognize that in this province French is a language common to all.")

161. Id. at 27 
its campaign promise when Bill $101,{ }^{162}$ the Charter of the French Language, ${ }^{163}$ became law on August 16,1977. It is a comprehensive linguistic plan designed to ensure the primacy of French in business, government, the professions, and education. The preamble to the charter sets out its main objectives:

... the French language, the distinctive language of a people that is in the majority French-speaking, is the instrument by which that people has articulated its identity; the Assémblee Nationale du Québec recognizes that Quebecers wish to see the quality and influence of the French language assured, and is resolved therefore to make of French the language of Gouvernement and the Law, as well as the normal and everyday language of work, instruction, communication, commerce and business;

the Assemblee Nationale du Quebec intends in this pursuit to deal fairly and openly with the ethnic minorities, whose valuable contribution to the development of Quebec it readily acknowledges; . . . . 164

After declaring French to be "the official language of Quebec,"165 the Charter then defines the following "fundamental language rights":

2. Every person has a right to have the civil administration, the health services and social services, the public utility firms, the professional corporations, the associations of employees and all business firms doing business in Quebec communicate with him in French.

3. In deliberative assembly, every person has a right to speak in French.

4. Workers have a right to carry on their activities in French.

5. Consumers of goods and services have a right to be informed and served in French.

6. Every person eligible for instruction in Quebec has a right to receive that instruction in French.

\section{B. A Comparison-Bill $22^{166}$ and Bill $101^{167}$}

An exact comparison of Bill 22 and Bill 101 is difficult but reference to only a few articles contained in each law reveals the dramatic differences.

Section 40 of Bill 22 provided that "[t]he school boards, regional school boards and corporations of trustees shall continue to provide instruction in English."168 This section applied to all school boards providing education in English in 1974 and thus actually guaranteed the right to English language instruction as opposed to section 93 of the BNA Act, which only guarantees Protestant education. The P.S.B.G.M. hypocritically failed to recognize this right in their protests and publicity. Bill 101 does not provide this most important guarantee to the English of

162. Originally the law was presented with a flourish as Bill 1, but the government had procedural difficulties in the House. Thus, instead of waiting the prescribed delays, Bill 1 was withdrawn and Bill 101 substituted. This short cut around the National Assembly rules caused considerable outrage, much of which was justified.

163. Charte de la langue française, ch. 5, 1977 Que. Stat. 55 (codified at QUE. ReV. STAT. ch. C-11 (1977)).

164. Id. (preamble).

165. Id., $\$ 1$. The Parti Québécois, when in the Opposition in 1974, had not wished to debate Bill 22 and had, therefore, filibustered for six weeks in committee and never progressed beyond section 1 . They proposed that section 1 read "only official language" (emphasis added), but section 1 of their own Bill 101 did not contain the word "only" when adopted three years later in 1977. In respect to French being the official language of Quebec, it is noteworthy that the Commissioner of official languages in his ANNUAL REPORT OF 1977, MINISTRY OF SUPPLY AND SER VICES, (1978), stated that "[i]n fairness, we should have little to question about this development, for with the exception of New Brunswick, much the same situation-but in reverse-prevails across the breadth of English-speaking Canada." Id. at 25.

166. Official Language Act, ch. 6, 1974 Que. Stat. 53.

167. Charter of the French Language, ch. 5, 1977 Que. Stat. 103.

168. Ch. 6, 1974 Que. Stat. $\S 40$. 
Quebec. By the fall of 1976, it was clear that the English school population was increasing at the expense of the French school population, and Bill 22 was therefore criticized for permitting too many students to enter the English system. Accordingly, Bill 101 is much more stringent in its requirements for French education. Sections 72 and 73 require:

72) Instruction in the kindergarten classes and in the elementary and secondary schools shall be in French, except where this chapter allows otherwise . . . .

73) In derogation of section 72 , the following children, at the request of their father and mother, may receive their instruction in English:

(a) a child whose father or mother received his or her elementary instruction in English, in Quebec;

(b) a child whose father or mother, domiciled in Quebec on the date of the coming into force of this act, received his or her elementary instruction in English outside Quebec;

(c) a child who, in his last year of school in Quebec before the coming into force of this act, was lawfully receiving his instruction in English, in a public kindergarten class or in an elementary or secondary school;

(d) the younger brothers and sisters of a child described in paragraph $\mathrm{c}^{169}$

Bill 101 has one major advantage over Bill 22 in respect to education in that the criterion for determining the right of access to English schools is much more clearly defined and applied-attendance in an English primary school in Quebec by one parent. Under Bill 22, pupils were required to demonstrate a sufficient knowledge of the language of instruction in order to receive their instruction in that language. Pupils who did not have a sufficient knowledge of either French or English were required to receive their instruction in French. ${ }^{170}$ Some pupils, therefore, had to be tested in order to determine their ability to receive English language instruction. The testing provoked bitterness and resentment, although only about 1200 students were tested annually. Most of those tested were children of parents who themselves spoke little English. Anglophone parents merely provided sworn affidavits, but this opened the way to deceit and false declarations. Bill 101, by excluding persons on the basis of status rather than ability, may appear to be quite harsh; ${ }^{171}$ but its simplicity and finality avoid many personal confrontations. Bill 22 required pupils instructed in English to obtain a knowledge of spoken and written French and French students a similar knowledge of English. ${ }^{172}$ There is no such provision in Bill 101.

169. Ch. 5, 1977 Que. Stat. $\S 72 \& 73$.

170. Ch. 6, 1974 Que. Stat. $62(\$ 41)$.

171. In respect to to article 73 of Bill 101, the Commissioner of Official Languages stated:

These provisions undoubtedly represent restrictions on parental freedom of choice, and as such we cannot support them. Nevertheless ... [one] might wish to keep in mind the glass house that is French education in the English-speaking provinces. The fact is that Quebec's English school system is still far more complete than any French school system in the other nine provinces. Furthermore, although freedom of choice for immigrants may exist in theory in other parts of the country, in the sense that it is not prohibited by law, it would be an exceptional immigrant who would in fact choose a French-language education for his children in most parts of English-speaking Canada . . . .

Thus, although the changes set out in the new law are distasteful to many, they do in fact entail very little, vis-a-vis immigrants from abroad, that is not already the case elsewhere in Canada . . . . The key to a resolution of the problem probably lies therefore in a reasonable compromise over the matter of free choice of language of instruction for persons moving from one province to another.

ANNUAL REPORT, supra note 165, at 27.

172. Ch. 6, 1974 Que. Stat. $\$ 44$. 
Bill 22 also gave every person the right to address the public administration in either French or English. There is no similar provision in Bill 101 except in some cases under section 15.

Bill 22 unequivocally provided that public signs must be drawn up in both French and English or in French and another language. In contrast, Bill 101 provides: "Except as may be provided under this act or the regulations of the Office de la langue française, signs and posters and commercial advertising shall be solely in the official language."173

Bill 22 required corporations to have a French name, but it also permitted an English version of that name and business under such an English name. More restrictively, Bill 101 states that "[f]irm names must be in French"174 and "[a] firm name may be accompanied with a version in another language for use outside Quebec. That version may be used together with the French version of the firm name in the inscriptions referred to in section 51 , if the products in question are offered both in and outside Quebec." 175

Bill 101 closely resembles Bill 22 in having as a primary objective the implementation of francization programs designed to generalize the use of French at all levels of businesses. There is, however, a notable difference. Under section 136 of Bill 101, firms with fifty or more employees must have a francization certificate by December 31, 1983. ${ }^{176}$ Under section 28 of Bill 22 the francization certificate was mandatory only for firms wishing to do business with the government. ${ }^{177}$

It should be noted that section 29(b) of Bill 22 required "francophone presence in management" 178 and initially some persons took the word "francophone" to mean French Canadian. This was an indication of the hysteria at the time and the extent to which people would go in finding fault with a law that in general was very reasonable. The regulations (in the drafting of which I played a considerable part) made it clear that Francophone meant anyone who could speak French. To its credit, Bill 101 does not mention Francophones or Anglophones. Section 141(b) requires: "an increase at all levels of the business firm, including the board of directors, in the number of persons having a good knowledge of the French language so as to generalize its use." 179

A comparison of the use of French and English in government, municipalities, school boards, universities, hospitals, and business illustrates the difference between the two laws. Biligualism under Bill 22 was replaced under Bill 101 with a form of French uniligualism whereby English was permitted only in certain circumstances.

173. Ch. 5,1977 Que. Stat. $\$ 58$ (emphasis added).

174. Id. at $\S 63$.

175. Id. at $\S 68$.

176. Id. at $\S 136$

177. Ch. 6, 1974 Que. Stat. $\$ 28$.

178. Id. at $\S 29(\mathrm{~b})$.

179. Ch. 5, 1977 Que. Stat. $§ 141$ (b). 


\section{Contestation of Bill 101}

Bill 101, like Bill 22, was challenged in the courts. In Blaikie v. Attomey-General of Quebec, ${ }^{180}$ the Court declared that articles 7 to 13 of the Charter of the French Language were ultra vires the Legislature of Quebec. The articles, comprising chapter III of the Charter, made French the official language of the legislature and courts in Quebec. ${ }^{181}$ More specifically, articles 7 to 13 of the Charter established the following: (1) only the French text of statutes is official; (2) an English version as well as the official French version of all bills, statutes, and regulations shall be printed and published by the government; (3) all procedural documents and pleadings before the courts must be in French unless otherwise agreed to by the parties; and (4) all judgments by Quebec courts must contain a French version and only the French version of the judgment is official. ${ }^{182}$

The Quebec Superior Court held that the contested articles were invalid in that they directly violated the language guarantees of section 133 of the BNA Act, 1867. ${ }^{183}$ Furthermore, the Court declared that it was not within the legislative competence of the Quebec National Assembly to unilaterally amend section 133, inasmuch as the section forms part of the Constitution of Canada and of Quebec in an "indivisible" sense. ${ }^{184}$

This decision was upheld by the Quebec Court of Appeal, where that Court found the relevant sections to be "en contradiction flagrante."185 On further appeal to the Supreme Court of Canada, the Court, in "matters of detail and history, [was] . . . content to adopt the reasons of Deschênes, C.J. as fortified by the Quebec Court of Appeal."186

In Devine v. Attomey-General of Quebec, ${ }^{187}$ the validity of articles 53 and 57 through 61 of the Charter of the French Language was challenged. The articles are part of Chapter VII and they require the following: (1) catalogues, brochures, and similar publications must be drawn up in French; (2) applications for employment, order forms, invoices, and similar items must be drawn up in French; (3) except as may be provided otherwise by regulation, signs, posters, and commercial advertising must be solely in French; (4) firms of fewer than four people may erect signs in both French and English so long as the French inscription is prominently displayed; and (5) signs of a particular ethnic group's cultural activities may be in both French and the language of that group. ${ }^{188}$

The plaintiffs sought a declaration that the contested articles were ultra vires the Quebec National Assembly, and alternatively, that the articles were incompatible

180. 85 D.L.R.3d 252 (1978).

181. Ch. 5, 1977 Que. Stat. $\S 8$ 7-13.

182. Id.

183. 85 D.L.R.3d 252, 270 (1978).

184. Id. at $280-81$.

185. [1978] C.A. 351, 361. (Translation: "in flagrant contradiction.")

186. 101 D.L.R.3d 394, 401 (1980). In response to the judgment of the Supreme Court the Quebec Government adopted a special statute, ch. 61, 1979 Que. Stat.

187. [1982] Que. C.S. 355.

188. Ch. 5, 1977 Que. Stat. $\$ \$ 53,57-62$. 
with the Quebec Charter of Human Rights and Freedoms, ${ }^{189}$ and thus void and inoperative.

With regard to the ultra vires issue, the plaintiffs first contended that the restrictions on the use of the English language caused them "prejudice dans leurs activités commerciales," and as such, the instant articles were an encroachment on the exclusive federal jurisdiction over the "regulation of trade and commerce." 190 The Quebec Superior Court rejected this argument in short order. It noted that the courts have long upheld the competence of provincial legislatures to enact legislation in the area of trade and commerce so long as the legislation concerned matters of a purely local nature. In this regard, the Court cited with approval a portion of the opinion in Shannon v. Lower Mainland Dairy Products Board:191

It is now well settled that the enumeration in $\mathrm{s} .91$ of "the regulation of trade and commerce" as a class of subject over which the Dominion has exclusive legislative powers does not give the power to regulate for legitimate Provincial purposes particular trades or businesses so far as the trade or business is confined to the Province. . . . And it follows that to the extent that the Dominion is forbidden to regulate within the Province, the Province itself has the right under its legislative powers over property and civil rights within the Province. ${ }^{192}$

The plaintiffs then maintained that the prohibition of English signs in section 58 was an encroachment on the federal power over criminal law under section 91(27) of the BNA Act, 1867. This argument was also rejected by the Court. In light of section 92(15) of the BNA Act, 1867, the Court stated that "une province a le droit d'utiliser le moyen de la prohibition pour atteindre une fin qui découle de sa compétence." 193 After deciding that the Province has "le droit . . . de légiférer sur la langue du commerce et des affaires," the Court determined that "la prohibition de l'art. 58 est un moyen d'atteindre le but de la loi qui est 'd'assurer la qualité et le rayonnement de la langue française' et de 'faire du français . . . la langue normale et habituelle du travail, . . . du commerce et des affaires.' "194 In addition, the Court declared that,

On peut dire que le moyen est radical, qu'il est sans mesure avec le besoin, la prohibition de l'article 58 ne cesse pas d'être un moyen légitimement choisi d'atteindre l'objectif légitime de la loi . . . Si la Province a droit de se donner un visage français, l'article 58 est certes un moyen efficace d'y parvenir . . . Il n'appartient pas à la Cour de se prononcer sur les motifs ou les objectifs du législateur. Je comprends la déception des demandeurs. Ce fut celle des francophones lors de l'ârret MacKell et j'ai appris à partager la déception dé mes professeurs d'histoire. Mais au point de vue du droit public anglais, MacKell est inat taquable. MacKell a fait la oi du pays. Il pèse de tout son pieds dans ce débat. Il me lie. ${ }^{195}$

189. Ch. 6, 1975 Que. Stat. 51 (current version at QUE. Rev. STAT. ch. C-12 (1977)).

190. [1982] Que. C.S. at 360. (Translation: "prejudice in their commercial activities.")

191. [1938] A.C. 708.

192. [1982] Que. C.S. at 361 .

193. Id. at 370 . (Translation: "a province has the right to use the means of prohibition to attain an end which arises from its competence.")

194. Id. at 370-71. (Translation: "the right . . to legislate concerning the language of commerce and business.")

195. Id. at 371 . (Translation:

It can be said that the method is a radical one, that it is out of all proportion to the need, the prohibition contained in section 58 is nevertheless a legitimately chosen means of fulfilling the legitimate purpose of the law .... If the Province has the right to take on a French character, section 58 is undoubtedly an effective way of reaching that goal. It is not part of the Court's function to rule on the 
The Court next considered the plaintiff's submission that article 58 was incompatible with articles 3 and 10 of the Quebec Charter of Human Rights and Freedoms.

3. Every person is the possessor of the fundamental freedoms, including freedom of conscience, freedom of religion, freedom of opinion, freedom of expression, freedom of peaceful assembly and freedom of association.

10. Every person has a right to full and equal recognition and exercise of his human rights and freedoms, without distinction, exclusion or preference based on race, colour, sex, sexual orientation, civil status, religion, political convictions, language, ethnic or national origin, or social condition.

Discrimination exists where such a distinction, exclusion or preference has the effect of nullifying or impairing such right. ${ }^{196}$

The plaintiffs submitted that the requirement imposed by article 58 of the Charter to use only French signs discriminated against them by reason of language. Furthermore, they argued that this restriction denied them freedom of expression. With regard to the first argument, the Court held that there was no discrimination by reason of language in that the sign law applied equally to all, regardless of language:

. . . la loi s'applique aussi bien aux francophones qu'aux anglophones, aux italiens qu'aux grecs, à la majorité qu'à la minorité. Il est évidemment plus facile aux francophones d'y obéir, mais cela ne dépend pas de la loi, cela dépend de la familiarité des francophones avec la langue obligatoire de l'affichage. . . . Les anglophones subissent plus que les autres ethnies l'obligation qui leur est faite de n'utiliser que la langue française dans l'affichage parce que, plus que les autres, ils ont utilisé leur langue à cette fin. Mais l'obligation de n'utiliser que le français s'impose également à tous et en ce sens, il n'y a pas de discrimination contre eux en raison de leur langue. ${ }^{197}$

The plaintiff's submission that the requirement to use French signs denied them freedom of expression was also rejected when the Court held that "La liberté d'expression ne comprend pas la liberté de choisir la langue d'expression."198 Freedom of expression, along with freedom of opinion, are "deux facettes d'une même liberté, la liberté de discussion." 199 The Charter of the French Language is not concerned with those matters, but only with "le code qui traduit la pensée-la langue, le dessin, l'image." 200 In this regard, the Court noted the distinction that

motives or objectives of the legislation. I understand the plaintiff' disappointment. This is the disappointment that Francophones felt after the MacKell decision, and I have learned to share the disappointment of my history professors. But from the standpoint of English public law, MacKell is indisputable. It has set the law of this country. It bears heavily upon this debate. I am bound by it.) 196. Ch. 6, 1975 Que. Stat. $\S 3,10$ (current version at QUE. REv. STAT. ch. C-12 (1977)).

197. [1982] Que. C.S. at 374-75. (Translation:

The law applies equally to Francophones and Anglophones, to Greeks and Italians, to the majority and the minority. Naturally, it is easier for Francophones to obey it, but this has less to do with the law itself than with the fact that Francophones are more familiar with the compulsory language for signs and posters. More than other ethnic groups, Anglophones suffer under the obligation imposed upon them to use only French for signs and posters because, more than others, they have been accustomed to using their own language for that purpose. But the obligation to use French applies equally to all, and in this sense they are not being discriminated against because of their language.)

198. Id. at 379. (Translation: "Freedom of expression does not include the freedom of choosing the language of expression.")

199. Id. at 376. (Translation: "two facets of the same freedom, the freedom of discussion.")

200. Id. at 375. (Translation: "the medium that transmits thought-language, drawing, picture.") 
exists in law between the message (beliefs, thoughts, opinions) and the medium of transmission ("le code").

During the course of its opinion, the Court engaged in a long discussion of a proposition put forward by the plaintiffs that the right to use a particular language is a "fundamental right." This proposition, according to the Court, had no basis in Canadian constitutional law. The Court noted that the MacKell"201 case determined that there are no substantive language "rights." The presumed legal right by the Francophones of Ontario to have their children educated in French was in reality a "privilege of a voluntary character."202

L'ârret MacKell si douloureusement ressenti par les francophones Ontariens, était malheureusement conforme au droit public anglais qui tient que l'étendue de nos libertes est la somme de ce qui n'est pas défendu. ${ }^{203}$

That language is not a "fundamental right" is confirmed by English constitutional law. The preamble to the BNA Act, 1867, states that the Canadian Constitution is to be "similar in principle to that of the United Kingdom."204 As far back as 1362, during the reign of Edward III, the use of French was forbidden in the courts of England. ${ }^{205}$ In 1535, Parliament prohibited the inhabitants of Wales from using their language in a court of justice. ${ }^{206}$

In 1733 the use of any language in the courts other than English was prohibited by statute. ${ }^{207}$ In 1840, the Parliament of the United Kingdom enacted the Act of Union ${ }^{208}$ which reunited the provinces of Upper and Lower Canada. Following the recommendations of the Durham Report, ${ }^{209}$ the statute sought to anglicize French Canadians. To that end, the Act abolished the use of French in the statutes and records of the Legislative Assembly. Henceforth, all such documents were to be "in the English language only." 210 In light of the foregoing statutes the Court in Devine v. Attomey-General of Quebec concluded: "Le droit constitutionnel anglais ne reconnaît pas a une minorité linguistique le droit de s'exprimer dans la langue de son choix."211

If the decision in Devine is disconcerting to some Anglophones, it is, nevertheless, a logical, reasonable, and just result achieved by carefully balancing the terms of contemporary law with its historical evolution.

\section{Regulations under Bill 101}

Title IV of Quebec's Language Charter (Bill 101) establishes a Conseil de la

201. [1917] A.C. 62 .

202. [1982] Que. C.S. at 365.

203. Id. at 362. (Translation: "The MacKell decision, which was so painful to the Francophones of Ontario, was unfortunately in accordance with English public law, which holds that the extent of our freedom is the sum of what is not forbidden under the law.')

204. BNA Act, supra note 6.

205. 1362, 35 Edw. 3, ch. 15, §15.

206. 1535,7 Hen. 8, ch. 26, $\S 20$ (cited by Dugas, J., [1982] Que. C.S. at 363).

207. 1731, 4 Geo. 2, ch. $26, \S 1$ (cited by Dugas, J., [1982] Que. C.S. at 363).

208. The Union Act, 1840, 3 \& 4 Vict., ch. 35 (U.K.); CaN. Rev. STAT. app. II, No. 4 (1970).

209. Lord Durham's Report on the AfFairs of British North AMERica (1912).

210. Can. Rev. Stat. app. II, No. 4, § 41 (1970).

211. [1982] Que. C.S. at 363. (Translation: "English constitutional law does not recognize the right of a linguistic minority to the language of its choice.") 
langue française to advise the government on questions relating to the interpretation and application of the Charter. ${ }^{212}$ In March of 1982, Yves Ouellette, Dean of Law at the University of Montreal, submitted a confidential report ${ }^{213}$ to the Conseil indicating that many of Quebec's language regulations were either clearly ultra vires the authority conferred by the Charter, or else of such questionable validity as to encourage challenges in the courts. Ouellette argued that the problems with respect to the regulations arise from the fact that many of the articles of the Charter are poorly drafted. Unfortunately, attempts were made to remedy the deficiencies and errors in the Charter by passing questionable regulations rather than by amending the law itself. In support of this criticism Ouellette concluded:

A vrai dire cependant, le malaise est infiniment plus profond; il découle de la Charte elle-même. D'un point de vue strictement technique, cette loi ne saurait être considérée comme un modèle de rigueur et de bonne rédaction. On a donc tenté d'en corriger les déficiences et les lacunes par voie réglementaire et c'est là que se situe le fond du problème. ${ }^{214}$

The regulations governing language tests prepared by the Office de la langue française and administered to members of professional corporations are now being contested in the courts. The Charter requires that all professionals practicing in Quebec have a knowledge of French "appropriate to the practice of their profession." 215 According to Ouellette, the language of the Charter is too general to be interpreted as conferring on a governmental agency the extraordinary power of control over the right to earn a living. ${ }^{216}$ To this end Ouellette noted: "ni l'article 35 ni les autres dispositions de la loi n'attribuent à l'Office la juridiction en cette matière. Les [réglements] pretendent corriger cette lacune importante de la loi." 217

\section{The Amendment to the Constitution-1982}

\section{A. The Canada Act, 1982}

Prior to 1981 , attempts to patriate the Canadian Constitution were unsuccessful because of the inability of the federal and provincial governments to unanimously agree on an amending formula. The defeat of the Quebec referendum on sovereignty-association in May of 1980 prompted renewed efforts by the federal government to bring about constitutional reform. A first ministers' conference four months later ended with the two levels of government still at an impasse; as a consequence, the federal government announced it would act unilaterally to break

212. Que. Rev. STAT. ch. C-11 (1977).

213. Y. OUellette, ETUde de la Validité des RéGlements Adoptés en Vertu de la Charte de la Langue Française (submitted to the Conseil de la Langue Française March 15, 1982).

214. Id. at 41. (Translation: "In effect, however, the malaise goes infinitely deeper; it derives from the Charter itself. From a purely technical standpoint, this law cannot be considered a model for clarity and good writing. An attempt has been made to correct its deficiencies by way of regulations, and therein lies the root of the problem.")

215. Ch. 5, 1977 Que. Stat. 108.

216. Ouellette, supra note 213 , at 16 .

217. Id. at 17. (Translation: "... neither section 35 nor the other provisions of the law give the Office jurisdiction over this matter. The [regulations] are intended to correct this major deficiency of the law.") 
the deadlock. It proposed sending a Resolution to Westminster requesting the United Kingdom Parliament to adopt the Canada Act, 1982.

The Resolution was to accomplish three things. First, it would patriate the constitution, thereby giving Canada full sovereign independence; no longer would the U.K. Parliament have the power to legislate for Canada. Second, a domestic amending formula would be included in order to permit future constitutional reform. Third, a charter of human rights and freedoms, including language rights, was to be entrenched as part of Canada's constitution.

Eight of the provinces, including Quebec, formed an alliance opposing the plan. After a lengthy filibuster in Parliament, the issue as to whether provincial consent was required was referred to the Supreme Court of Canada. ${ }^{218}$ On September 28, 1981, the Court ruled that as a matter of law, the federal government could send the Resolution to Westminster without provincial consent. ${ }^{219}$ The Court also held, however, that a constitutional convention requires "substantial" provincial agreement in order to permit constitutional change. ${ }^{220}$ Following the Supreme Court's decision, negotiations between the two levels of government resumed. Another first ministers' conference was held, and on November 5, 1981, all of the provinces except Quebec gave their consent to the historic Resolution. Four days later, in a speech before Quebec's National Assembly, Premier René Levesque voiced his contempt for the new agreement:

Il est donc clair que nos ne pouvions absolument pas accepter cette nouvelle constitution
fabriqueé en une nuit de fourberies. D'abord, parce qu'elle nous aurait forcés à accepter
une limitation importante des pouvoirs exclusifs de l'Assemblée nationale en ce qui con-
cerne la langue d'enseignement dans nos écoles. Je l'ai dit et je le répète: Aucun gouverne-
ment québécois qui se respecte ne pourra jamais abandonner la moindre parcelle de ce
droit absolument fondamental pour la protection du seul îlot français dans la mer
anglophone du continent nord-américain.

Notwithstanding Quebec's dissent, ${ }^{222}$ the Resolution was adopted by the House of Commons on December 2, 1981, and by the Senate on December 8, 1981. The Canada Act 1982 was in turn adopted by the United Kingdom House of Commons and House of Lords, and received royal assent on March 29, 1982. The Constitution Act, 1982, being schedule B of the Canada Act 1982, was brought into force by a proclamation signed by Her Majesty the Queen in Ottawa on April

218. Reference re Amendment of the Constitution of Canada, 125 D.L.R.3d 1 (1982).

219. Id. at 7-9.

220. Id. at $3-6$.

221. 26 JOURnAl des débats 4 (Nov. 9, 1981)(Translation:

It is therefore clear that we absolutely cannot accept this new constitution created in a night of double dealing. First of all, because it would force us to accept a significant limitation to the exclusive powers of the Assemblée Nationale with respect to the language of instruction in our schools. I have said it before and I repeat: No self-respecting Quebec government could ever abandon the smallest fraction of this absolutely fundamental right to protect the only French island in the English-speaking sea of the North American continent.)

222. It is now settled that Quebec's consent is not essential for constitutional reform. In a recent reference to the Quebec Court of Appeal [1982] Que. C.A. 33; 134 D.L.R.3d 719 (1982), Quebec maintained that as one of the founding nations of Canada, it enjoyed a veto power over proposed constitutional changes. This argument was rejected by the Court. 134 D.L.R.3d at 720. Furthermore, the Court declared that Quebec's consent to the Resolution was not necessary because only substantial agreement was required. Id. at 726 . 
17, 1982. ${ }^{223}$ The Canadian Charter of Rights and Freedoms comprises Part I of the Constitution Act, 1982.

\section{B. Official Languages of Canada}

The provisions respecting the official languages of Canada comprise sections 16 to 22 of the Canadian Charter of Rights and Freedoms. These provisions create no new language rights. ${ }^{224}$ Several of the sections maintain existing constitutional guarantees, while the others constitutionally entrench existing statutory provisions.

Sections 17(1), 18(1), and 19(1) reproduce the language rights binding on the federal government under section 133 of the BNA Act, 1867, by establishing that (1) everyone has the right to use either English or French in Parliament, (2) legislative materials and statutes of Parliament shall be published in English and French with each given equal authority, and (3) either English or French may be used in any judicial pleadings or process in any court established by Parliament. ${ }^{225}$ Sections 17(2), 18(2), and 19(2) of the Act entrench identical provisions for New Brunswick. ${ }^{226}$ These provisions were originally conferred by provincial legislation in $1969 .{ }^{227}$

Section 16 declares French and English to be the official languages of Canada and New Brunswick, and gives each language equality of status in all institutions of both governments. The Act entrenches statutory provisions enacted over a dozen years ago by the federal government ${ }^{228}$ and the legislature of New Brunswick. ${ }^{229}$

Section 16(3) confirms that legislation in respect to language is a matter of concurrent jurisdiction divided between the two levels of government. Although it is clear that Parliament and the provincial legislatures are free to advance "the equality of status or use of English and French"230 beyond the minimum standards established by the Charter, it is not certain whether the legislatures must exclusively pursue that objective. There are many ways in which Parliament or the provincial legislatures might diminish the status or use of one of the two languages, and still

223. Canada Act 1982, 1982, ch. 11 (U.K.).

224. It has been argued that the equality rights secured by section 15(1) of the Canadian Charter of Rights and Freedoms prohibit discrimination based on language. This argument is at best tenuous. It is not easy to disregard the fact that language is specifically omitted from the prohibited forms of discrimination listed in section 15(1), which only includes "race, national or ethnic origin, colour, religion, sex, age, or mental or physical disability." Canada Act 1982, 1982, ch. 11 (U.K.), Part I, $\S 15(1)$. Admittedly, the prohibited forms of discrimination are not exhaustive, but rather are only particular ways in which equality before the law is not to be denied. Nevertheless, given the crucial importance of the language issue in Canada, the failure to include language among the prohibited forms of discrimination cannot be summarily dismissed as a mere oversight on the part of the legislators. If they had intended the section to apply to language, it is clear that they would have included it in the list.

225. Canada Act 1982, 1982, ch. 11 (U.K.), Part I, §§ 17(1), 18(1) \& 19(1).

226. Id. at $\S \S 17(2), 18(2)$ \& $19(2)$.

227. Official Languages of New Brunswick, N.B. REv. STAT. $\S \S 3,4,6,7,13$ (1973). See supra text accompanying note 84 . 18.

228. Official Languages Act, CAN. Rev. Stat. ch. 0-2, $\$ 2$ (1970). See supra text accompanying note

229. N.B. REV. STAT. ch. 0-1, § 2 (1973). See supra text accompanying note 69.

230. Canada Act 1982, 1982, ch. 11 (U.K.), Part I, § 16(1). 
not violate any of the guarantees found in the Charter. Quebec's sign law ${ }^{231}$ is an example of such provincial legislation.

Section 20 ensures that members of the public will be able to communicate with and receive services from the federal government and the government of New Brunswick in the official language of their choice. ${ }^{232}$ Again, this section entrenches existing statutory provisions. ${ }^{233}$ While Quebec's Charte de la langue française does not guarantee government services in English, it does permit the use of a language other than French in "correspondence between the civil administration and natural persons when the latter address it in a language other than French."234

Section 21 of the Canadian Charter preserves existing constitutional language rights by providing that "[n]othing in sections 16 to 20 abrogates or derogates from any right, privilege or obligation with respect to the English and French languages, or either of them, that exists or is continued by virtue of any other provision of the Constitution of Canada."235

\section{Minority Language Educational Rights}

French and English minority language education supported by public funds up to the university level is now constitutionally guaranteed (where numbers warrant) by section 23 of the Canadian Charter of Rights and Freedoms. Under section 23(1)(a), Canadian citizens (a) whose first language, learned and still understood is French or English, or (b) who have received their primary school instruction in Canada in French or English, are guaranteed the right to have their children receive primary and secondary school instruction in that language. ${ }^{236}$ In addition, if any child has received or is receiving primary or secondary school instruction in English or French, the parents of such a child have the right to have all their children instructed in that language. ${ }^{237}$ These rights are guaranteed so long as there are sufficient children to justify the use of public funds for minority language instruction. ${ }^{238}$ Finally, the section also provides that where there are sufficient numbers requiring minority language instruction, educational facilities supported by public funds for minority language instruction will be made available. ${ }^{239}$

Section 23 is one of the most controversial provisions of the Canadian Charter. The Quebec government has argued that the section seriously encroaches upon provincial autonomy in the area of education and, by extension, presumably undermines Quebec's ability to preserve and protect its unique linguistic and cultural identity. ${ }^{240}$ As a concession to Quebec, section 59 of the Constitution Act,

231. Charter of the French Language, ch. 5, $\S 58,1977$ Que. Stat. 111-12.

232. Canada Act 1982, 1982, ch. 11 (U.K.), Part I, § 20(1).

233. Official Languages Act, CAN. REv. STAT. ch. 0-2, $\S 9$ (1970); Official Languages of New Brunswick Act, N.B. REV. STAT., ch. 0-1, § 10 (1973).

234. Charter of the French Language, ch. 5, § 15, 1977 Que. Stat. 105.

235. Canada Act 1982, 1982, ch. 11 (U.K.), Part I, § 21.

236. Id. at $\S 23(1)$.

237. Id.

238. Id. at $\S 23(2)$.

239. Id. at $\$ 23(3)(\mathrm{a})$.

240. See supra text accompanying note 222 and infra text accompanying note 246 . 
1982, stipulates that section 23(1)(a) will come into force in respect to Quebec only when authorized by the legislative assembly or government of Quebec. ${ }^{241}$

Shortly after the Constitution Act, 1982, came into force the Quebec government adopted legislation to ensure that such authorization will be given only with the consent of the National Assembly. Section 4 of An Act Respecting the Constitution Act, 1982 (Bill 62) provides: "[ $t]$ he Government shall not authorize a proclamation under subsection 1 of section 59 of the Constitution Act, 1982, without obtaining the prior consent of the National Assembly of Quebec."242

A comparison of section 23(1)(b) of the Canadian Charter of Rights and Freedoms with article 73(a) of the Charte de la langue française brings into sharp relief the differences that exist between Ottawa and Quebec over minority language educational rights. Section 23(1)(b) of the Canadian Charter stipulates that any child whose parents were educated in English in Canada has the right to receive his or her school instruction in English. ${ }^{243}$ In contrast, section 73(a) of the Quebec Charter provides that such a right is guaranteed only to children whose parents were educated in English in Quebec.

The clash between the two sections reveals the opposing objectives of the two pieces of legislation. Broadly speaking, the purpose of the Canadian Charter is to ensure that French and English-speaking citizens can move freely throughout the country, secure in the knowledge that at least with respect to educational and federal government institutions, certain language rights will be uniformly recognized. This view directly conflicts with Quebec's Charte de la langue française, which is designed to protect Quebec's distinctive French culture. The Quebec government has expressed a willingness to protect the status of English schools in Quebec, but this does not include the right of the English in Quebec to maintain their numbers through contributions from the rest of Canada. ${ }^{244}$ As Laurin stated in the white paper:

Par ailleurs, s'il y a lieu de garantir à la minorité anglaise du Québec l'accès à l'école anglaise, il est légitime de s'assurer que les personnes qui viendront s'installer au Québec dans l'avenir enverront leurs enfants à l'école française. En d'autres mots, l'école anglaise, qui constitue un système d'exception accordé à la minorité actuelle du Québec, doit cesser d'être assimilatrice et doit donc être réservée à ceux pour qui elle a été créée. ${ }^{245}$

Undoubtedly, Laurin's description of English schooling as "a special privilege granted to the present minority of Quebec" prompted the adoption of Bill 101's language of instruction provisions.

On May 5, 1982, several weeks after the Canadian Charter of Rights and Freedoms came into force, Camille Laurin issued an eight-page declaration in which

241. Schedule B, Canada Act 1982, 1982, ch. 11 (U.K.).

242. Ch. 21, 1982 Que. Stat.

243. Canada Act 1982, 1982, ch. 11 (U.K.), Part I, $\S 23$.

244. Toronto Globe \& Mail, Aug. 9, 1977 at 9, col. 2 cited in Note, Language Rights and Quebec Bill 101, 10 CASE W. Res. J. INT'L LAW 543, 552 (1978).

245. Laurin, supra note 154, at 46. (Translation: "Moreover, if it is fitting to guarantee access to English schooling to Quebec's English minority, it is legitimate to ensure that, in the future, those who settle in Quebec will send their children to French schools. In other words, English schooling, which is a special privilege granted to the present minority of Quebec, must cease being an assimilating force and must be reserved to those for whom it was created.") 
he announced on behalf of the Quebec government that section 73 of Bill 101 would continue to apply in full force:

Cette loi de la langue française au Québec est enracinée dans la légitimité la plus authentique, je dirais même la plus sacrée, et aucun texte légal, émanant d'un autre pouvoir, ne saurait prévaloir contre elle.

(...)

En qualité de Ministre de l'Education et de Ministre responsable de l'application de la Charte de la langue française, je tiens à reaffirmér clairement, sereinement mais fermement, que la loi 101 continuera de s'appliquer intégralement, dans toutes ses parties, sous tous ses aspects et a l'echelle du Québec tout entier. ${ }^{246}$

As the next school year approached, the constitutional validity of section 73 was challenged in the courts. In Quebec Association of Protestant School Boards $v$. Attorney-General of Quebec, ${ }^{247}$ a declaration was sought that the restrictions on access to English language education contained in section 73 of Bill 101 were inconsistent with section 23 of the Canadian Charter of Rights and Freedoms, and therefore of no force or effect.

The Quebec Superior Court found that section 73 and section 23 are incompatible, and that by virtue of section 52 of the Constitution Act, 1982, "the Canada clause (section 23) must prevail. ${ }^{248}$ However, the Court noted that section 52 must be read with section 1 of the Charter, which stipulates that the rights and freedoms guaranteed by the Charter are "subject only to such reasonable limits prescribed by law as can be demonstrably justified in a free and democratic society."249

The Attorney-General for Quebec put forward an argument that section 73 of Bill 101 did not involve a denial of a right, but only a limitation, since the right to English education secured by section 23 was a collective right established for the benefit of the English-speaking minority as a group. "The limitation on this collective right," so the argument ran, might "well involve the loss of the right by certain members of the collectivity, but the right is not denied to the group as a whole: it is simply limited."250

This argument is susceptible to the kind of criticism that has often been levelled against utilitarianism: it would justify sacrificing the interests of the few in order to promote the interests of the many, thus violating the principle that each and every human being has equal intrinsic worth. With justifiable indignation, the Court denounced the "collective rights" argument:

246. Declaration of the Minister of Education and Minister responsible for the application of the Charte de la langue française, M. Camille Laurin, in conjunction with the tabling of Bill 62, An Act respecting the Constitution Act, 1982, May 5, 1982, p. 2. (Translation:

This law concerning the French language in Quebec has its roots in the most authentic, I would even say the most sacred, legitimacy and no legal text emanating from any other power, can prevail over it.

**

In my capacity as Minister of Education and Minister responsible for the application of the Charte de la langue française, I wish to reaffirm, clearly, calmly, but firmly, that Bill 101 will continue to apply as written in all its parts, in all aspects and throughout the whole of Quebec.).

247. 140 D.L.R.3d 33 (1982). For the French judgment, see [1982] Que. C.S. 673.

248. 140 D.L.R.3d, at 48 .

249. Id.

250. Id. at 64 . 
Quebec's argument is based on a totalitarian conception of society to which the court does not subscribe. Human beings are, to us, of paramount importance and nothing should be allowed to diminish the respect due to them. Other societies place the collectivity above the individual. They use the Kolkhoze steamroller and see merit only in the collective result even if some individuals are left by the wayside in the process.

This concept of society has never taken root here-even if certain political initiatives seem at times to come dangerously close to it-and this court will not honour it with its approval. Every individual in Canada should enjoy his rights to the full when in Quebec, whether alone or as a member of a group; and if the group numbers 100 persons, the one hundredth has as much right to benefit from all the privileges of citizens as the other ninety-nine. ${ }^{251}$

Even if section 73 of Bill 101 constituted a "limit" within the meaning of section 1 of the Charter, the Court ruled that Quebec failed to satisfy all of the conditions stipulated in section 1. In particular, the Court held that section 73 exceeded "reasonable limits" in that it was disproportionate to the admittedly legitimate objective of "solidifying the French fact in America."252 The Court found that the operation of section 23 would not "have a negative effect in the area of the language of instruction which is still, as a rule, French," and that "the influx of new students into the English language school system because of section 23 of the Charter would be negligible."253

The decision of the Superior Court was upheld by the Quebec Court of Appeals on June 9, 1983 (as yet unreported), ${ }^{254}$ and it is expected there will be an appeal to the Supreme Court.

Since the Canadian Charter of Rights and Freedoms has come into force, the rancour between Ottawa and Quebec has continued unabated. Indeed, Premier Levesque has threatened to make independence the theme of the next general election in Quebec.255 Thus, it is clear that far from resolving the "language problem," the new Constitution has exacerbated the division between Ottawa and Quebec.

It should be pointed out that unlike the fundamental freedoms enumerated in section 2 or the legal and equality rights set out in sections 7 to 15 of the Canadian Charter, the language rights are not subject to the notorious "notwithstanding" clause of section 33 whereby: "Parliament or the legislature of the province may expressly declare in an Act of Parliament or of the legislature, as the case may be, that the Act or a provision thereof shall operate notwithstanding a provision included in section 2 or sections 7 to 15 of this Charter."256 The language guarantees are binding on both the federal and provincial governments in respect to all matters falling within the authority of each legislature.

The constitution may be amended in respect to the use of the English or the French language in one of two ways. First, section 41 prescribes the normal procedure: "by proclamation issued by the Governor General under the Great Seal of Canada only where authorized by resolutions of the Senate and House of Com-

251. Id.

252. Id. at 70 .

253. Id. at 89 .

254. Levesque Vows Language Fight, Toronto Globe \& Mail, June 11, 1983, at 11.

255. P.Q. Retums to Independence Hard Line, Toronto Globe \& Mail, June 13, 1983, at 8.

256. Canada Act 1982, 1982, ch. 11 (U.K.), Part I, § 33. 
mons and of the legislative assembly of each province."'257 Second, section 43 prescribes the procedure to amend any provision that relates to the use of the English or the French language within a province: "by proclamation issued by the Governor General under the Great Seal of Canada only where so authorized by resolution of the Senate and House of Commons and of the legislative assembly of each province to which the amendment applies."258 An amendment to section 133 of the BNA Act, 1867, insofar as it applies to Quebec, and similarly the proposed amendment ${ }^{259}$ to the language provisions of the Manitoba Act, 1870, would be accomplished according to the latter formula.

\section{SchoOling in Quebec}

\section{A. Private Schools-Bill 56}

Private education in Quebec began over three centuries ago when, in the early part of the seventeenth century, Quebec was colonized by Roman Catholic settlers from France. At that time, the idea of a public school system was foreign to the French regime and responsibility for education was left to the Roman Catholic Church. The subsequent years witnessed a gradual growth of government involvement in public education, but the tradition of private education remained strong and continues to this day. Currently, private schools are far more numerous in Quebec than in any other Canadian province. Even more important, they receive a level of public financial support that is virtually unprecedented in the western world.

Until the 1960's the public and private sectors operated quite independently of each other; rapid changes in Quebec's social, political, and economic milieu, however, created pressure for educational reform. The Parent Commission on Education, ${ }^{260}$ organized in 1961, recommended that a more unified educational system be established. To that end, it proposed that legislation be adopted to bring about "collaboration, integration and coordination" between the two school systems. ${ }^{261}$

The Commission made additional recommendations. Indeed, because of concern about the quality of education in the private sector and possible abuses, the Commission recommended that the state exercise a degree of supervision and inspection over all private schools. ${ }^{262}$ This was to ensure that certain uniform standards relating to curricula and teaching qualifications were satisfied. The state was required to assume such duties, according to the Commission, as "a consequence of the responsibility it bears with regard to everything which affects the public interest and the welfare of the people."263 The Commission also proposed that the system of government grants to private schools should be made commensurate with the schools' ability to serve the public and to contribute to educational

257. Id. at Part $\mathrm{V}, \S 41.2$.

258. Id. at $\S 43$.

259. See, supre text accompanying notes 52 and 53 .

260. 1966 Report of the Royal Commission of Inquiry on Education in the Province of

QUEBEC 115. [hereinafter cited as REPORT OF THE ROYAL COMMISSION].

261 . Id. at 207.

262. Id. at 219 .

263. Id. 
progress in Quebec. ${ }^{264}$

Many of the recommendations of the Parent Commission were incorporated into Bill 56, Private Education Act, ${ }^{265}$ introduced by the Union Nationale Government in December of 1968 . When presenting the Bill, Jean-Marie Morin, then Minister of Education, recognized the special status of private schools in Quebec: "Nous devons dire que la liberté de l'enseignement n'a jamais été contestée au Québec, et que les institutions privées ont pu naître et se developper librément sous l'oeil bienveillant et souvent même avec l'aide de l'État qui n'exerçait qu'un controle minimal, parfois même insuffisant."266 While acknowledging that the private schools have made a valuable contribution to education in Quebec, Morin nevertheless pointed out that the private schools all too often functioned at the fringe of the school system, thereby undermining efforts to create a unified and coordinated school system. In addition, Morin noted the difficulties caused by the precarious financial position of many private schools.

To ensure that the private schools would have "les moyens de continuer leur oeuvre bénéfique,"267 Bill 56 provided that private schools declared to be "of public interest" and which satisfied certain regulations designed to ensure teaching quality and the advancement of education in Quebec would receive a government grant "equal to eighty percent of the average cost per pupil, as computed for the preceding school year for public establishments of the same class. . . ."268

The Bill also authorized the Minister of Education to recognize "for the purposes of grants" private schools not declared to be "of public interest."269 These schools were to receive sixty percent of the average cost per pupil in comparable public institutions so long as they satisfied certain regulations. ${ }^{270}$ Bill 56 was unanimously adopted by the National Assembly in December of 1968 and it remains law today, although modified somewhat by Bill 101 in section $72 .^{271}$

Camille Laurin's 1982 white paper ${ }^{272}$ on educational reform reiterates the state's "responsibility for monitoring the quality of services" 273 provided by private institutions. Laurin, however, also cautions, as did the Parent Commission, ${ }^{274}$ that " $[\mathrm{t}] \mathrm{he}$ right to private education does not, in itself, confer any inherent right to receive public funds for this purpose."275

The reasons for the popularity of private schools today include the high quality of education, the greater discipline, the personal attention, and the extra-curric-

264. Id.

265. Ch. 67, 1967-68 Que. Stat. 445 (codified at Que. REv. STAT. ch. E-9 (1977)).

266. 1968 Journal DES DÉBats 5015. (Translation: "It must be said that freedom of education has never been contested in Quebec, and that private schools were created-and developed freely-with the blessing and even the help of the state, whose control was minimal and sometimes insufficient.")

267. Id. (Translation: "the means to continue their useful work.")

268. Que. Rev. STAT. ch. E-9, § 14 (1977).

269. Id. at $\S 15$.

270. Id. at $\$ 16$.

271. Ch. 67, 1967-68 Que. Stat. 445.

272. C. Laurin, The Quebec SchoOl: A Responsible Force IN the Community (deposited in the National Assembly on June 21, 1982). See infra text accompanying notes 292-94.

273. Id. at 82 .

274. Report of the Royal Commission, supta note 260.

275. C. LAURIN, supra note 272 , at 82. 
ular activities which are not always found in public schools. Children otherwise ineligible for English instruction because of Bill 101 are able to attend English private schools, but such children do not qualify for the appropriate government grants to the private schools as provided by section 72 of Bill 101 . Section 72 is an ambiguous provision untested in the courts and its total effect on the entire grant to a school at which an unqualified student attends is far from clear.

\section{B. Public Schools and the Laurin White Paper}

Since before Confederation, the public school system in Quebec has been organized along Roman Catholic and Protestant denominational lines. Generally, this has run parallel to a division between French- and English-speaking pupils. In 1978, ninety-two percent of the students enrolled in Catholic schools in Quebec were taught in French, while ninety-eight percent of the students enrolled in Protestant schools were educated in English. ${ }^{276}$

Various attempts to reform the denominational and linguistic dualism of Quebec's schools date back to the Parent Commission. In 1966, the Commission recommended in its report that the denominational character of Quebec's school boards be abolished and replaced by unified school boards responsible for "Roman Catholic, Protestant and non-confessional education, insofar as the requirements for quality in education can be satisfied in each instance." 277 The Commission further recommended that the new unified school system "be made up, by law, of both French and English schools." ${ }^{278}$ Thus, at least in theory if not in practice, the possibility existed that a school board might administer no fewer than six types of schools.

By the summer of 1967, the key recommendations of the Parent Commission gained the support of the Conseil supérieur de l'éducation and the Catholic Committee of the Council. The Protestant Committee, however, strongly opposed the creation of unified school boards. In the fall of 1967, the Union Nationale government established a Council to examine more closely the problem of restructuring more than forty school boards on the Island of Montreal. The Page Report of $1968^{279}$ rejected the idea of unified school boards, and favoured instead the creation of school boards organized along linguistic lines. It recommended that nine French-language and four English-language boards should be established on the Island of Montreal, with the former responsible for Catholic and pluralist (nondenominational) schools, and the latter responsible for Catholic, Protestant and pluralist schools. ${ }^{280}$ Moreover, several minority opinions were submitted with the Pagé Report, one of which favored retention of confessional division, while another proposed unification of the school boards. ${ }^{281}$

On November 4, 1969, Jean-Guy Cardinal, then Education Minister for the

276. Minority Language Education Report, supra note 67, at 137.

277. REPORT OF THE ROYAl COMMISSION, supra note 260 , at 85.

278. Id. at 115 .

279. C. LAURIN, supra note 272 , at 8 (reviewing the recommendations made by the Conseil de restructuration scolaire de l'île de Montréal in the Rapport Pagé).

280. Id.

281. Id. 
Union Nationale Government, presented Bill 62, An Act Respecting School Organization on the Island of Montreal. The Bill proposed replacing the existing Protestant and Catholic school boards on Montreal Island with eleven unified school boards, each responsible to administer "l'enseignement catholique, l'enseignement protestant et l'enseignement autre que catholique ou protestant aux enfants de leur territoire." 282 The Bill also provided for the formation of school committees "compose de parents des éleves et chargé de veiller à la qualité de l'enseignement"'283 and an overall Montreal Island School Council responsible for financing and co-ordinating the activities of the eleven school boards.

Bill 62 made no mention of minority-language schooling, and this provoked criticism from the English-language community. According to Cardinal, the reason for the absence of language provisions in Bill 62 was simply that Bill 62 was conceived as companion legislation to Bill 63. ${ }^{284}$ Unlike Bill 63, however, Bill 62 was never passed. The proposed legislation died on the National Assembly's order paper amidst the controversy and uproar generated by Bill 63 .

Following the defeat of the Union Nationale in the next general election, the Liberal government continued to pursue the objective of educational reform. Bill $27,{ }^{285}$ dealing with the regroupment and integration of school boards along denominational lines off the Island of Montreal, was adopted on July 11, 1971 . Unlike Bill 27, however, Bill 28, 286 introduced by the then Education Minister, Guy Saint-Pierre, was never adopted.

Bill 28 was an improved version of the controversial Bill 62. Similar to Bill 62, it provided for the replacement of Montreal Island's forty-three Catholic and Protestant school boards with eleven unified boards under a central Council. Each school board was to be responsible for Catholic, Protestant, and non-denominational schooling in both English and French. Bill 28 also proposed the creation of parent-student advisory committees for each school to assess the quality of education.

Unlike Bill 62, which made no provision for minority-language schooling, Bill 28 required each school board to offer its multidenominational services "également adaptés aux réalités linguistiques de chaque secteur de l'île." 287 Bill 28 required English and French-speaking personnel to be appointed to senior administrative positions on each school board. Moreover, the bill provided for the hiring of the necessary administrative staff in the academic, student, and personnel services of each school district for the English- or French-speaking minority, depending upon which linguistic sector was in that position. An additional protection for minoritylanguage groups was found in a clause permitting appointment by the government

282. 1969 Journal des Débats 3509. (Translation: "the Catholic education, Protestant education and education other than Catholic and Protestant of children under their jurisdiction.")

283. Id. (Translation: "composed of the parents of students and charged with watching over the quality of instruction.")

284. See supra text accompanying notes 118-21. 493.

285. An Act Respecting the Regrouping and Management of School Boards, ch. 67, 1971 Que. Stat.

286. An Act Respecting the Reorganization of School Boards, 1971 Journal DES DEBATS 3059.

287. Id. (Translation: "equally adapted to the linguistic realities of each sector of the island.") 
of two additional school commissioners in any district where the minority-language group was insufficiently represented. Thus, examined from the point of view of minority language rights, Bill 28 was an equitable document.

The P.S.B.G.M. reacted to Bill 28 with characteristic concern and hostility. The P.S.B.G.M. chairman, A. Reid Tilley, said the proposed legislation threatened "the whole web and woof of the English and North American culture." 288 In a letter directed to parents, Tilley stated:

[i]t is the considered opinion of the Protestant School Board of Greater Montreal that unifying at the school board level offers few advantages, needlessly duplicates and complicates the administrative and pedagogical processes in each Board and will so fragment the Englishlanguage minority that they will in due course lose their individual identity and cultural values. ${ }^{289}$

Not surprisingly, the Parti Québécois felt Bill 28 did not contain enough guarantees for the French language. The P.Q. staged a lengthy filibuster on the language issue shortly before Christmas in 1971 and as a consequence Bill 28 was subsequently dropped. As a compromise, Bill 71,290 adopted in December of 1972, regrouped the existing Montreal Island school boards into six Catholic and two Protestant school boards. Bill 71 also established an Island School Council responsible for financing and co-ordinating common services of the school boards. The problem of restructuring, however, was far from resolved.

In 1976, an ad hoc committee of the School Council proposed that the government create French-Catholic, French-neutral, English-Catholic, and English-Protestant school boards. This recommendation was rejected by the Council, which in turn submitted a recommendation to the Minister of Education proposing that the status quo be maintained, but with two improvements-the creation of a nonconfessional sector in Catholic school boards, and better means of representation for linguistic minorities. ${ }^{291}$

Little action was taken regarding the matter of restructuring the school boards on Montreal for another five years. In June 21, 1982, however, Camille Laurin, Minister of Education for the P.Q. government, deposited in the National Assembly a white paper on educational reform. ${ }^{292}$ In accordance with recommendations dating as far back as the Parent Commission ${ }^{293}$ of the 1960's, the white paper proposes abolishing the existing denominational school boards, and replacing them with unified regional boards drawn up along geographical lines. Each school will then decide whether it wishes to operate as a Protestant, Catholic, or non-denominational institution. On the Island of Montreal, the white paper recommends that school boards should be drawn up along linguistic lines with eight French-speaking and five English-speaking school boards. This is precisely what the P.S.B.G.M. suggested over a decade ago during the debate over Bill

288. Montreal Star, Sept. 8, 1971, at 3.

289. Letter from P.S.B.G.M. to parents (Sept. 17, 1971)(emphasis added).

290. An Act to Promote School Development on the Island of Montreal, ch. 60, 1972 Que. Stat. 1127 (now Part 9 of the Education Act, Que. Rev. STAT. ch. I-14 (1977)).

291. C. LAURIN, supra note 272 , at 10.

292. Id.

293. Report OF the Royal Commission, supra note 260. 
28. 294 The white paper also recommends that linguistic committees be established off the Island of Montreal where a school district has at least three English schools whose students represent at least ten percent of the total student population. The responsibility of these linguistic committees includes administration over most of the affairs of the English schools.

Already, the proposed reforms, particularly the creation of linguistic committees, have proved to be very debatable. Alliance Quebec, recently formed to represent the interests of English-speaking Quebecers, has denounced the committees as "totally inadequate" and has threatened court action. 295 Whether this reaction is justified remains to be seen. Nonetheless, it appears that all too often in the past, the fear of losing privileges has motivated the English in Quebec to resort to impassioned rhetoric and little real study of proposals with the net result that reasoned negotiation has been nearly impossible. Compromise this time requires a more calm, careful appraisal of the proposed reforms, and a genuine effort to reach a fair and proper solution. ${ }^{296}$

\section{Conclusion}

It is clear that the Canadian Constitution has done very little to promote or even protect Canada's two great languages which should have been-and should be today - a great national asset. The British North America Act, 1867, failed to protect the French language and culture which were violated in such judgments as Ottawa Separate Schools Trustees v. MacKell or such legislative action as Manitoba's Official Language Act, 1890, and Regulation 17 of Ontario.

The constitution as interpreted by the courts should have provided a high standard of conduct, a spirit of natural justice, and a tradition of fair play. Instead, there was often harshness and no apparent legal recourse. It was only in the 1960's that political action in Quebec, beginning with the quiet revolution, brought about change. This occurred not only in Quebec but in the rest of Canada as well, where in varying degrees the enormity of the situation was finally acknowledged. But change in Quebec was too quick for the English and change in the rest of Canada was too slow for the French. Understandably, change of any kind causes animosity and mistrust because most individuals are naturally conservative and usually content with the status quo unless one's own personal interests clearly dictate otherwise.

The result has been a loss of Canadian unity. This is particularly unfortunate

294. Letter, supra note 289.

295. Montreal Gazette, June 23, 1982, at 2, col. 2.

296. Bill 40, An Act Respecting Public Elementary and Secondary Education, was tabled in the Quebec National Assembly on June 20, 1983. There are some changes from the White Paper. The Bill calls for five French and three English school commissions for Montreal Island, with 143 French and 10 English commissions covering the rest of the province. To forestall a constitutional challenge, Quebec's four original Protestant and Catholic school boards will be permitted, if they so choose, to retain their denominational status as provided by section 93 of the BNA Act, 1867. However, in such a case, they would revert to their original boundaries of 1867. The original boundaries of the Protestant School Board of Greater Montreal encompass an area now known as "Old Montreal." There are no schools in "Old Montreal." A court challenge can certainly be expected. 
because bilingualism unquestionably is a great personal and national asset. Indeed, it has been said that one does not know one's own language completely and properly until a second is learned. Canada is amply blessed with two major languages-English and French-both of which are leading languages in the world of culture and commerce. It is significant and more than a little ironic that the only other major source of conflict and disunity in Canada is geographic disparity in our other great blessing - abundant natural resources; this latter conflict, incidentally, closely resembles our linguistic problems.

Although our two linguistic cultures have not aided unity or national understanding or even provided a large body of bilingual Canadians, quite clearly the imbalance towards the French language has been largely rectified. This has been, however, greatly outweighed by antipathy towards manifestations of French linguistic culture by certain English Canadians and an aversion by some Quebecers towards English Canadians.

Perhaps the most unfortunate consequence of the animosity has been its contribution towards the exodus of English-speaking Montrealers and business from Montreal. The great metropolis of the past which should have been a world center of commerce because of its bilingualism is now becoming a branch office community. Will the new constitution of 1982 rectify the situation? It is unlikely to remedy the situation in the short run and, in fact, its creation has only caused even greater estrangement and exacerbated already present linguistic animosity. The new constitution includes the Canadian Charter of Rights and Freedoms, but it has been so tempered by special arrangements entered into with various provinces in order to gain their participation that the Charter is no longer a document of dignity, of refuge, of hope, or of justice. Rather, it sonorously presents balkanized human rights and optings out on a zig zag geographical plan.

Despite the present situation, I am optimistic for the future of Quebec and Canada. Most other bilingual Quebecers and I are content and at home in Quebec, a doubly and truly enriched culture. Furthermore, I also find that a major change has overtaken many (but not all) Quebecers-there is a spirit of understanding among some of the young, both French and English, who realize that one cannot be unilingual anymore. It is this growing spirit that makes me sanguine about the future of Canada. And if the youth of the rest of Canada are not and cannot be bilingual, they nevertheless seem to have an openness of mind and of the heart that their elders have not revealed. There is hope! 
